\title{
Deregulating Teacher Labor Markets
}

Simon Burgess

Ellen Greaves

Richard Murphy

Discussion Paper 19 / 717

26 August 2019

器

Department of Economics

University of Bristol

Priory Road Complex

Bristol BS8 1TU

United Kingdom 


\title{
Deregulating Teacher Labor Markets
}

Simon Burgess ${ }^{a}$, Ellen Greaves ${ }^{b}$, Richard Murphyc

\author{
August 2019
}

\begin{abstract}
A common feature of public sector labor markets is the use of pay scales. This paper examines how the removal of pay scales impacts productivity, by exploiting a reform that compelled all schools in England to replace pay scales with school-designed performance related pay schemes. We find that schools in labor markets with better outside options for teachers saw relatively higher increases in teacher pay. Schools in these areas relatively increase their spending on teachers, have higher teacher retention and larger improvements in student tests scores. These effects are largest in schools with the high proportions of disadvantaged students. We conclude that the pay rigidities in the form of centralized pay schedules result in a misallocation of resources, by preventing such schools from retaining their teachers.
\end{abstract}

\section{JEL classification:}

Keywords: Pay Scales, Teachers, Performance Related Pay, Productivity

Acknowledgements: This project derives from work commissioned by the Department for Education to evaluate the impact of the national teacher pay reforms, which we conducted with the National Foundation for Educational Research. Our thanks are due to the project Steering Group for their advice during that process and to the Department for Education for commissioning the work and granting access to the longitudinal School Workforce Census dataset. We would like to thank Sandra Black, Andrew Barr, Steve Trejo, Hans Sievertsen, Anna Vignoles and Yanos Zylberberg for their advice. Neither NFER nor the Department for Education bear any responsibility for any findings reported here.

\footnotetext{
a University of Bristol, IZA, Simon.Burgess@bristol.ac.uk

b University of Bristol, IFS, ellen.greaves@bristol.ac.uk

cUniversity of Texas at Austin, NBER, IZA, CESifo, CEP, richard.murphy@austin.utexas.edu
} 


\section{Introduction}

Public sector labor markets around the world are typified by being bureaucratic. An individual's pay is typically based on observable characteristics (experience) and divorced from performance (productivity). This inflexibility also precludes organization from reacting to local labor market conditions. Of course, there may be good reasons not to have strong performance pay in the public sector such as lack of competition, non-verifiable output, multiple tasks, and motivated agents (Dixit, 2002) ${ }^{1}$. However, there are also costs, particularly through reduced incentives for effort (Woessman, 2011).

In this paper we use a pay reform that required public sector providers to stop using pay scales and switch to a more flexible pay structure, to examine the impact on productivity. Flexible pay allows organizations to react more easily to local conditions, and to incentivize individual productivity by varying pay within the organization. Pay that is unresponsive to both individual productivity and to local conditions is also likely to lead to misallocation of resources between labor and other inputs.

The productivity of many public sector occupations is difficult to measure. Therefore, we estimate the impact of increased pay flexibility in the education sector, using student performance on national exams as a measure of productivity. The pay reform ended the use of 'annual progression' pay scales in all schools in England and from September 2013 required (not just 'permitted') all 20,000 plus state-funded schools to introduce their own pay for performance scheme. In doing so, the reform completely changed the basis for setting pay, affecting the whole labor market of close to half a million teachers in the public sector (DfE, 2018d) and half of school budgets (DfE, 2018b). Despite the scale of the changes to pay regulations, there were no changes to the way schools were financed, which allows us to isolate the impact of pay rigidities.

This de-coupling of pay from experience means that, in principle, schools could vary pay as they wished. We split the changes to teacher pay into two parts: changes in school-level average teacher pay, and changes to the within-school variation in pay across teachers. Both

\footnotetext{
${ }^{1}$ In labor markets where it is difficult to measure individual productivity there are potential advantages to have a pre-specified pay schedule; 1 ) it reduces the effort employees will spend on politicking; 2 ) any incentive structure which is not perfectly aligned with intended outcomes will be inferior to a pay scale with motivated agents; 3 ) removes this risk of moral hazard on behalf of the employer (not rewarding effort).
} 
aspects have substantial histories of research. First, the level of teacher pay relative to other occupations has been argued to affect teacher quality and therefore pupil outcomes (Nickell \& Quintini, 2002). In this case, deregulation allows schools to set their pay relative to the local labor market (see Britton \& Propper, 2016). Second, within-school variation in pay increases are a feature of teacher performance-related pay systems (see the survey in Neal, 2011); here the deregulation explicitly requires schools to link teacher pay to teacher performance.

This reform, in combination with newly available administrative data on individual teacher pay, allows us to contribute to both literatures. When schools have a free hand on pay, what do they do? Specifically, we use this reform to address three key questions. First, do public sector organizations change pay when given the freedom to do so? Second, how do these changes impact the labor supplied? Third, does the decentralization of pay improve productivity?

We exploit the pre-reform variation in wages across local labor markets in England to test how schools react to increased pay flexibility. This is estimated in a difference-in-differences framework, with school and year effects. We use the pre-reform mean hourly wage of the labor market in which the school resides as a dosage treatment post reform. We are therefore estimating the relative reactions made by schools according to local wages. Schools in areas where the pay scales happen to coincide with the local market clearing level of wages will be unaffected by the reform. Taken to an extreme, if pay scales were perfectly aligned with all local labor markets, we would not see any reactions to the reform. Therefore, we interpret the sign and magnitude of our dosage parameter as the extent to which the pay scales took schools away from market clearing equilibria.

The focus of this paper is on pay and pay regulation and therefore we need to abstract from compositional changes in the teacher workforce. To account for this, we create an individual teacher-level counter-factual expected annual pay growth which would have occurred under the old scale point system (see Section 4 for details). This allows us to consider deviations from expected pay progression, which automatically accounts for relevant teacher demographics. We aggregate the teacher pay measures to the school average deviation from expected growth, and within-school variance of deviation from expected growth. 
The data on teacher wages is obtained from the School Workforce Census, an annual census of every public sector teacher in England from 2010. The reform, and our study, encompasses both primary schools, serving children aged 4 through 11, and secondary schools, serving children through to age 16 . We combine this teacher data with administrative data on: student performance at ages 11 and 16 from the School Performance Tables and prereform local labor market earnings from the Annual Survey of Hours and Earnings. Together, these data allow us to causally estimate how the removal of teacher pay scales affects how schools pay teachers; allocate resources; retain and recruit teachers; and ultimately affect student attainment. Together, these data allow us to make four contributions to the literature via four distinct findings.

Our first finding is that after the reform teachers' salaries grow faster in tighter labor markets. Post reform there is an immediate general decrease in teacher pay grow $\mathrm{th}^{2}$, but this decrease is smallest in labor markets with high non-teacher wages. A $£ 1$ increase in the local median hourly wage leads to an $0.15-0.17$ percent higher than expected pay growth. To scale the size of the effect, primary schools at the $75^{\text {th }}$ rather than the $25^{\text {th }}$ percentile of local wage distribution increase teacher salaries by an additional 0.43 percent points (£120) annually. In addition, we find that primary schools in high wage areas relatively increase the dispersion of pay growth, indicating that these schools are implementing performance related pay by increasing pay of select teachers.

The second finding is that schools in more competitive markets increase the number of teachers they employ. The fact that schools were free to recruit additional teachers prior to the reform implies that this is a supply response to higher wages. Furthermore, there is no increase in the number of newly hired teachers, meaning that the schools are using their funds to retain their existing teachers.

Our third finding is that schools in more competitive markets achieve higher growth in student test scores. For each pound local median hourly wages increase, primary (secondary) schools post reform experience a $0.014(0.033)$ standard deviation increase in student test scores. The gains in student test scores are larger in schools with more disadvantaged student populations, implying that these schools were the most negatively impacted by the national

\footnotetext{
${ }^{2}$ Due to macroeconomic conditions and central government budget cuts on education.
} 
pay scales. We find that the majority of the test score gains occurred during the first year of the reform before pay or the quantity of teachers employed were able to change, implying that much of these initial gains are due to increased teacher effort.

Finally, not all types of teachers gained the same from the decentralization of pay. One of the features of having a bureaucratic pay scale in a labor market with hard to observe productivity is to reduce the impact of biases and nepotism. We find that the removal of the pay scales leads to males experiencing 0.38 percent higher pay growth compared to females, conditional on school effects. Moreover, teachers with longer tenures at the school also experience higher pay growth. While we cannot say if these relative differences in pay are due to productivity/demand rather than bias/nepotism, we can say that they would not have occurred under the pay scale system.

There are several papers on the importance of pay flexibility for productivity (Kessler 1990, Grimshaw, 2000, Buchan \& Black 2011). Most closely related to this work examines the teacher labor market, which, as noted earlier, provides an excellent laboratory in which to study the effects of reduced bureaucracy in pay structure on productivity. Our findings are consistent with Britton and Propper (2016) who find that students in labor markets where teacher wages are below market wages perform worse on standardized tests. Our method builds upon theirs by exploiting the changes over time due to the reform in addition to the geographical variation in outside wages, which allow us to account for school specific unobservable factors.

Biasi (2017) examines school districts in Wisconsin who were given the freedom to not use teacher pay scales. Biasi finds that districts that opted out of pay scales had increased dispersion of wages, and that individual salary was positively correlated with teacher valueadded (productivity). A key difference between Biaisi's paper and our own is that in England all schools were required to move away from pay scales, which removes the issue of endogenous selection. Moreover, in our setting, individual schools set teacher pay rather than the school districts. 
Willén (2018) studies the removal of national teacher pay scales in Sweden. ${ }^{3}$ The paper examines how pay at the municipality-gender-year level changes after a five year transition period. Willén finds regions with higher outside wages average salary increases more, as in our case, but there is no improvement in student attainment. A key difference is that we consider immediate short run impacts of pay deregulation, where the supply of teachers and schools is fixed. In contrast, the impact after a transition period, which included wage guarantees, risks confounding the effects with schools or teachers entering or exiting the market. Second, Willén finds that the municipality-gender inter-quartile range of teacher salaries decreased. However, this could be driven by pay rising faster for younger teachers relative to more experienced teachers, resulting in a reduced overall variation in pay. Our paper uses individual level difference from expected pay growth aggregated up to the school level, and so avoids the confounding issue of teacher characteristics, allowing us to focus only on the variation due to changes in salary.

The rest of the paper is structured as follows: Section 2 describes the English teacher labor market and the nature of the reforms. Section 3 briefly sets out the theoretical predictions and empirical design. Section 4 describes the data and how we calculate the expected pay increases. Section 5 presents the results, robustness tests and heterogeneity analysis. Lastly, Section 6 discusses implications for public sector pay regulation and concludes.

\section{Institutional setting}

\section{a. Pre reform}

Prior to September 2013 there was a national pay scale for teachers in England. ${ }^{4}$ Teachers' base salary was determined by their scale point, which in turn was determined by their total years of experience as a teacher in the UK. There were six scale points on the main pay scale (M1-M6) and progressing to the next point was automatic at the end of each academic year. ${ }^{5}$

\footnotetext{
${ }^{3}$ Söderström (2006) evaluates the impacts of the same Swedish reform, but with fewer outcomes and a shorter time horizon.

${ }^{4}$ For non-teaching staff the pay and conditions were determined locally. Schools can employ such staff on fixed or temporary contracts.

${ }^{5}$ Pre-reform schools had the authority to award additional payments to teachers for a set of predefined reasons; recruitment and retention payments, teaching and learning responsibility payments and payments for teachers working with children with special educational needs. However, in practice that these options were rarely used; 9 percent of schools used recruitment and retention payments, 10
} 
At the top of this pay scale teachers could move on to the upper pay scale if approved by the headteacher (Burgess et al, 2001). The upper pay scale had three points (U1-U3) and each year around 45 percent of teachers at M6 moved to U1, with progression to each higher point increasingly unlikely (DfE, 2012). ${ }^{6}$ In addition to experience, there are four geographic pay bands ('Inner London', ‘Outer London', 'The Fringe' and 'The rest of England'), which account for the cost of living around London. Despite large variations in wages and the cost of living in the rest of England and Wales, teacher salaries, given experience, were constant.

The pay at each of the scale points was updated annually by the government to account for inflation, budgetary and policy demands, advised by the School Teacher Review Body (STRB). Teacher salaries are paid from the school's budget, therefore any centralized pay increase had implications for school budgets.

Some schools, known as Academies, were not required to follow the national teacher pay schedule even before the 2013 reform. These are funded directly by the Department for Education, are outside Local Authority control, and are not required to follow the national curriculum. ${ }^{7}$ The 2010 Academies Act encouraged all maintained schools to convert to academy status, prior to this act there were 203 academies in England. By the time of pay the reform 3,146 (15 percent) schools were academies (DfE 2018c). Our main analysis includes all types of schools to sidestep any worries about endogenous selection into academy status. ${ }^{8}$

\section{b. The reform}

In 2012, the Secretary of State for Education asked the School Teachers' Review Body (STRB) to review current provisions for teachers' pay. The STRB recommended replacing the pay schedule with a broad national pay framework which contained minima and maxima for teacher and leadership pay ranges (DfE, 2012). The key recommendation was that all pay progression was linked to performance rather than length of service (abolishing the national

percent used special education payments and 3 percent paid newly qualified teachers above M1 (DfE 2012).

${ }^{6}$ The intention of the upper pay scale was to provide a mechanism through which headteachers could keep highly effective teachers in the classroom, rather than moving into management or leaving the profession. However such flexibility could only be used when the teacher was at the top of the pay scale.

${ }^{7}$ Academy schools are the English equivalent of the US charter schools.

${ }^{8}$ In robustness Table 6 we show estimates excluding and only including ever academy schools. 
scale points) and schools no longer had to match a teacher's existing salary when recruiting staff (relaxing 'pay portability').

This key recommendation was accepted, the reforms to teachers' pay came into force in September 2013, and first affected teachers' pay awards from September 2014. However, the STRB continued to produce recommendations for the teacher pay scale increases and using these recommendations teachers' unions continued to produce updated national pay scales. In September 2014 the same principle of autonomy was extended to the pay of school leaders (headteachers, deputy headteachers and assistant headteachers). Again, these reforms were mandatory for regular schools ("Local Authority maintained" schools) and voluntary for academies, who already had the opportunity for pay flexibilities for teachers and leaders.

A notable feature of these reforms is the deliberately non-prescriptive way in which they were introduced. The Department for Education (DfE) issued general advice to schools (DfE, $2013 b$ ) in which the definition of 'performance' was left for schools to specify in their pay and appraisal policies. The result is that headteachers determined how teacher performance would be measured, whether individual teachers met them, and ultimately the level of teacher pay. Neither teacher unions nor senior teachers have an official role in the wage setting of other teachers.

Note that the reform did not impact school funding. Schools receive block grants based on the size and composition of their student body. Headteachers decide how this funding is allocated across school resources. The funding gradually decreased in real terms on a per pupil basis throughout the period, but there were no discontinuous jumps (Belfield, Farquharson \& Sibieta, 2018).

\section{c. Implementation}

In conjunction with the National Foundation for Educational Research we conducted a nationally representative survey of 900 schools in the spring of 2015 to evaluate the implementation of the policy (DfE, 2017). ${ }^{9}$ We found that almost all Local Authority (LA) maintained schools $(99 \%)$ reported to have revised their pay policies following the

\footnotetext{
${ }^{9}$ This survey was funded by the Department for Education.
} 
introduction of pay reforms. Despite academies not being directly affected by the reforms a majority (62\%) of them also reported making changes to their pay policies.

The Department for Education provided little guidance on how to determine teacher performance; consequently, headteachers reported drawing on a range of different sources of support, including government documents (85 percent), the Local Authority (84 percent), teaching unions (64 percent) and other local schools (61 percent). The survey found that most schools were concerned with the time costs involved with introducing a new evaluation metric and so continued to use teacher evaluation methods that were already in place. The most common types of evidence used in evaluations by both maintained schools and academies were: teacher assessed pupil progress; classroom observations; teacher standards; measures linked to the school improvement plan; and pupil attainment. We find no significant differences between the types of evidence used by maintained schools and academies.

When asked about the impact of the pay reforms only 7 percent of headteachers reported that they had had an impact on teacher recruitment, but a third of headteachers said that pay reforms had already had a positive impact on their ability to keep their existing teachers (DfE, 2017).

\section{Theoretical Predictions and Estimation Strategy}

\section{a. Conceptual Framework}

Headteachers in England have strong incentives to improve student performance as parents are free to exercise school choice and funding follows student enrollment. We assume that headteachers take decisions to maximize expected pupil attainment at the school. They are responsible for hiring and firing teachers, and, post reform, can also determine teachers' pay.

How a headteacher reacts to the reform will depend on a range of factors, one of which is the local labor market. Consider a range of local labor markets that vary in their productivity $p \sim u(0,1) \cdot{ }^{10}$ This can be interpreted as agglomeration effects impacting all labor within a geographic region, which allows labor to be mobile but assumes constant returns to labor. Or,

\footnotetext{
${ }^{10}$ Much of the existing literature simplifies this into a dual-region model with a high and low productivity region (Britton and Propper 2016; Cardullo 2015; Propper and van Reenen 2010; Cappelli and Chauvin 1991).
} 
we assume labor to be immobile and the variation in wages reflects differences in the underlying productivity of labor. Aspects of both are likely to hold in the UK where geographic mobility of labor is low, ${ }^{11}$ and there is large variation in median wages across regions (Table 2).

Error! Reference source not found. presents a simple illustration of the impact of pay scales. A low productivity region $\underline{p}$ will have lower market clearing wages $\left(w_{1}^{\underline{p}}\right)$ than a high productivity region $\bar{p}\left(w_{1}^{\bar{p}}\right)$. However, having a national pay scale for teachers sets the same wage across regions $\left(w_{0}\right)$. This will result in an over-supply of teachers in the low productivity regions, and under-supply in the high productivity regions. In Error! Reference source not found. $L_{0}^{\bar{p}}$ is the labor demanded in high productivity regions and $L_{0}^{\underline{p}}$ is labor demand in low productivity regions, under a national pay scale regime. Teachers will be paid a higher relative wage in $\underline{p}$ compared with $\bar{p}$, which may result in higher productivity individuals choosing to become teachers, or teachers applying more effort (Shapiro and Stiglitz 1984) in these areas. Evidence of national pay scales having such effects on productivity by region have been found in the health (Propper and van Reenen, 2010) and education sectors (Britton and Propper 2016).

The removal of a national pay scheme would allow headteachers in high productivity regions to offer higher salaries to attract and retain productive teachers. In contrast, headteachers in low productivity regions may take this opportunity to reduce salary to the wage clearing level for their local labor market. Therefore, our first testable hypothesis is that schools in high-wage regions will have higher salary growth than low-wage areas post reform, $\left(w_{1}^{\bar{p}}-w_{0}\right)-\left(w_{1}^{\underline{p}}-w_{0}\right)>0$.

The other effect of the removal of pay scales is that employment in both regions will increase. In high wage areas, the increase in teacher salary will attract more teachers $L_{1}^{\bar{p}}>L_{0}^{\bar{p}}$. In low wage areas, where schools were required to pay over the market rate, they will now pay lower wages but employ more teachers $L_{1}^{\underline{p}}>L_{0}^{\underline{p}}$. A priori the relative size of these changes in employment is ambiguous. If employment increases relatively more in high wage labour markets, then the pre-reform market equilibrium was closers to market clearing level of

\footnotetext{
${ }^{11}$ In England and Wales 4.4 percent of residents move between local authorities per year (ONS 2016a).
} 
employment in low wage markets. To test this, the second hypothesis is that the pre-reform equilibrium is closer to market clearing level of employment for low wage areas $\left(L_{1}^{\bar{p}}-L_{0}^{\bar{p}}\right)>$ $\left(L_{1}^{\underline{p}}-L_{0}^{\underline{p}}\right)$.

Finally, given that headteachers allocate resources between teacher and non-teacher inputs to maximize pupil attainment, we would expect to see schools that make larger changes have larger improvements in student outcomes. Before the reforms, spending on teachers was constrained by national pay scales and regulations on pupil-teacher ratios. Therefore, schools' expenditure on teachers could only be adjusted through the experience profile of the teachers they employed. After the reforms, headteachers could re-optimize their spending on teacher by reducing or increasing teacher pay more than the expected progression. Therefore, any change in resources allocated to teachers implies that the schools did not have an optimal allocation when pay was regulated. Therefore our third testable hypothesis is that is that schools which changed relatively more, had larger relative gains in student test scores.

\section{b. Estimation Strategy}

To test these hypotheses, we use a difference-in-differences framework using a dosage treatment, comparing the decisions made by schools pre and post reform, in areas varying in their levels of labor productivity. Formally:

$$
Y_{\text {sta }}=\alpha+\text { ppost }_{t} * \text { wages }_{a}+\gamma_{t}+\theta_{s}+\varepsilon_{\text {sta }}
$$

Where $Y_{s t a}$ is the outcome of interest for school $\mathrm{s}$ in year $\mathrm{t}$ in Local Authority a. Our main outcomes of interest at the school-level are: school-average difference in pay from expected progression; the within-school variance of the difference from expected pay progression; the school proportion of overall spending on teachers; and, school-average student outcomes. post is an indicator for the years after the reform (2014 and 2015), and wages is the median hourly wage in the local authority in 2011. Therefore, $\beta$ is the parameter of interest which represents the relative change in outcomes due to the reform, giving the change in outcome for an increase in local median wages of $£ 1$.

Any national changes in these outcomes over time are captured by a set of year fixed effects, $\gamma_{t}$. The average of these coefficients in the post period represent the change in outcomes after the reform, but could not be interpreted as the impact of the reform without 
the strong assumption of there being no other time varying factors. Any time-invariant differences in outcomes across schools are captured by the inclusion of school fixed effects, $\theta_{s}$. There are multiple schools in the same Local Authority, and therefore this accounts for local area characteristics, in addition to differences at the school level.

Identification of $\beta$ is reliant on the standard difference-in-differences assumptions. First, that that there is no systematic difference in the year effects between schools in high and low wage areas e.g. the year effects, $\gamma_{t}$, are sufficient to capture the variation in outcomes over time. Second, that there are no other contemporaneous changes that are correlated with the pre-reform wages of teachers e.g. the school effects, $\theta_{s}$, are sufficient to capture the variation across Local Authorities. In the robustness section we present event diagrams of the reform establishing that prior to the reform schools in high and low wage areas had similar trends in teacher pay, teachers employed and student achievement.

\section{Data}

\section{a. The School Workforce Census}

The School Workforce Census (SWC) consists of individual-role level data on all staff from all local authorities and state-funded schools in England (including academy and LA maintained schools). Each teacher is given a unique identifier which can be used to track them over time. The Census is conducted on the first Thursday in November, each year since 2010; it is a statutory requirement for each school to submit a return. We use data from the SWC from 2010 to 2015.

There are two important limitations to the SWC data, which should be kept in mind throughout. First, significant changes to the way that the SWC recorded pay coincided with the reform we study. Whilst these changes were accounted for in the data cleaning, and with the inclusion of year effects, it is not possible to determine the full impact that these changes might have had. Second, the SWC may not record all relevant school pay decisions in a timely fashion. This is because some schools did not report the pay award decision by the census date. Under the most pessimistic assumption, this might have affected up to $32 \%$ of classroom teachers in 2015. This will not bias our results if these factors are uncorrelated with Local Authority wages. 
The SWC has 2,923,109 observations from 20,115 schools, including information on 650,501 teachers and 70,697 leaders. The final sample of schools used for analysis contains 2,132,762 teacher-year observations from 19,901 schools. Teachers are defined in line with DfE guidance. ${ }^{12}$ This sample excludes those with erroneous values of nominal base pay that could not be reasonably adjusted. The sample also includes: only schools classified as primary and secondary schools; excludes special schools, LA nursery schools, pupil referral units, studio schools and university technical colleges; includes only schools in which more than half of teachers have (recoded) base pay observed; includes individuals aged 22 and above and 62 and below ${ }^{13}$; includes individuals who work at least five hours per week and at least five weeks per year. The numbers of observations dropped in each stage of this sample selection are given in Appendix 2; in total this removed 16\% of teacher observations. ${ }^{14}$ Taking all teachers on the main pay scale leads to a sample of 941,222 teacher-year observations from 19,817 schools. ${ }^{15}$ Note, our main analysis sample is also restricted to the schools which have all outcome measures in all years, leaving 652,737 teacher-year observations from 16,610 schools. Robustness Table 6 shows that the results are not impacted by these restrictions.

Panel A of Table 2 shows teacher-level descriptive statistics for the school workforce for each census from 2010 to 2015. The reform was introduced in September 2013, so the first year it could affect teacher pay progression was 2014. There are some compositional changes to the teacher population; for example, the proportion of 'newly qualified' teachers increased from 0.2 to 0.26 between 2010 and 2015. This reflects a general trend in England's state-funded schools for higher teacher turnover and attrition (Foster, 2018). This compositional change

\footnotetext{
12 Teacher: Advanced Skills Teachers, classroom teacher (upper pay range and main pay range), Excellent Teacher and Leading Practitioner. This excludes leaders: Advisory Teacher, Assistant Head, Deputy Head, Executive Head, Head.

${ }^{13}$ These ages are chosen as age 22 corresponds to the 1st percentile and age 62 corresponds to the 99th percentile. This means that $1 \%$ of the sample with the lowest recorded age in the longitudinal SWC and $1 \%$ of the sample with the highest recorded age in the longitudinal SWC are excluded from the analysis. This decision was taken to remove observations with recorded ages at the extremes of the age distribution.

${ }^{14}$ Complete details of this sample reduction and cleaning is described in full in Appendix 1.

Complete Stata syntax is also available from the authors on request.

${ }^{15}$ In robustness checks we both remove the restriction that teachers must be on the main pay scale and limit the sample to those below the top of the main pay scale, as these teachers were not certain of progression to the next spine point (on the upper pay scale) before the reforms.
} 
highlights the importance of accounting for pay progression (as we do) rather than basing analysis on teacher pay levels.

\section{b. Defining pay progression}

In the pre-reform period, there were fixed teacher pay scales. Teacher pay was dependent on experience and location, meaning that the expected annual pay progression for each teacher is known in advance. Table 1 presents the main pay scale for teachers in England and Wales in 2012, where spine point 1 denotes a newly qualified teacher. For example, in Inner London a teacher in their third year would receive a salary of $£ 29,889$ and expect a salary of $£ 31,446$ in the following year, a 5.2 percent pay increase. If there was a 1 percent increase to the pay scales, due to government recommended cost of living adjustment, then this teacher would then expect a 6.2 percent pay increase.

To abstract from teacher composition and inflation in the measure of pay progression, our main measure of teacher pay is the percentage point deviation from the expected progression. In the example above, if the teacher in Inner London had received a pay increase of $£ 1,000$ (3.3 percent) rather than the expected $£ 1,557$ (5.2 percent) then the difference from expected progression would be -1.9 percentage points. We take the mean of all teachers on the main pay scale in a school to compute the mean school difference from expected pay growth. Our second measure of teacher pay is the school level variance in the difference from expected progression. Both measures have the feature that any non-zero value represents a movement away from the status quo. Prior to the reform we would expect there to be no difference from expected growth, and no variation in the difference from expected growth.

Pay scales and scale points were removed from guidance from the Department for Education following the reforms. However, the pay scales and scale points continued to be produced by teaching unions, based on the scale points before the reforms and national advice on inflation increases from the School Teachers' Pay Review Body. We use the scale points used by teaching unions after the reforms to continue our measure of difference from expected progression. If the unions artificially inflated the adjustment (which is unlikely as it was based on the School Teachers' Pay Review Body recommendations) this would be accounted for with the inclusion of year effects. 
Panel A of Table 2 shows levels and growth of individual level salary. In the years prior to the reform the annual raw growth in salary was $8.42 \%$ (2011) and $6.26 \%$ (2012). This variation is due in part to changes in government policies which directly impact the pay scale, ${ }^{16}$ and partly due to variation in the composition of the teaching workforce. As schools have no control over the former, we use the difference from the expected gains in salary.

Prior to the pre-reform 61 percent of teachers have exactly the increase in pay as predicted by the teacher pay scales (Table 2). From discussions with the Department for Education we strongly suspect this relatively low figure is due to the salary data not being updated by the time of the SWC: some teachers are recorded as remaining at the previous years' scale point, and other teachers recorded as jumping two points as the previous year's increase was not recorded. Error! Reference source not found. presents histograms of the differences from expected pay growth for teachers outside of London. We limit Error! Reference source not found. in this way to highlight the consistency in the difference from the expected growth, as the non-London regions are on a single pay scale, so remaining at the same spine point will represent the same below expected pay increase. This is what we observe in the years prior to 2014. Around 95 percent of teachers had pay increases exactly as expected, or a belowexpected pay increase consistent with the salary data not being updated, or an above-expected pay increase consistent with the salary being updated for a previous gap.

From 2014, the first year the reforms should impact teacher pay, we see a large decrease in the proportion making exactly the expected progress post reform (Error! Reference source not found.). Only 30 percent of teachers saw the exact expected salary progress, with most teachers now receiving lower than expected progress. This immediate reduction in teacher pay growth after the reform is indicative of schools using their new freedoms to spend less of the budget on increasing teacher salaries. Moreover, note that there is now dispersion in the below expected pay increase measure, consistent with schools moving away from the pay scale, although it appears that many teachers were held at the previous spine point. By 2015 this dispersion from spine points had increased again.

\footnotetext{
${ }^{16}$ The public sector pay freeze meant that there was no inflation adjustment for teachers' pay in 2011 and 2012. Classroom teachers' pay was uprated by $1 \%$ in 2013, the minima and maxima of the pay scales were uprated by $1 \%$ in 2014, and in 2015 the minima was uprated by $1 \%$ and maxima for teachers on the main pay scale was uprated by $2 \%$.
} 
Panel B of 
Table 2 presents the school-level statistics used in the main analysis. Consistent with Figure 2 this also shows the national decrease in teacher pay growth post reform, with the mean difference from expected pay growth decreasing from -2.7 to -3.7 percentage points, alongside an increase in the within school variation in expected pay growth.

\section{c. Other Data Sources}

Our main measure of the competition for teachers is the median hourly wage in the schools' Local Authority. This is a relevant measure for the demand for teachers as schools compete with other employers for labor. Bamford and Worth (2017) find that $40 \%$ of (non-retiring) teachers that leave the state education sector find work in another sector. There are 343 Local Authorities in England, with an average population of 215,000 in 2014 (ONS, 2016b). Panel A of

Figure 3shows the variation in median hourly wages of all employees across Local Authorities in England. Hourly wages are higher in London and the South East, although there is variation across the rest of the country.

In addition to this main competition measure, we use three other indicators to reflect the teacher labor market. The first of these is intended to reflect the tightness of the teacher labor market directly. For this we create an index using principal component analysis to combine the percentage of teachers with a permanent contract, non-temporary contract, and the percentage of spending on teachers on supply teachers in each school. Higher values are associated with attributes we associate with a tighter teacher labor market. ${ }^{17}$ Panel B of

\footnotetext{
17 This measure is standardised to have a mean of zero and standard deviation of one in our final sample for the analysis.
} 
Figure 3 shows the average of this measure at the Local Authority level. Again, there is more competition between schools in urban areas, particularly in London and Greater Manchester.

The second is the competition schools face from private schools. As there are far fewer private schools than state schools (ten state schools for each private school (Green et al. 2008)), we use the density of private schools at the local authority level. This is defined by the number of private schools in the Local Authority divided by the area of the Local Authority in square kilometers divided by $1,000,000$. This is shown in Panel C of

\section{Figure 3.}

The third measure of competition reflects the supply of new teachers. This is a binary variable, taking the value 1 if there is a Higher Education Institution that delivers Initial Teacher Training for the primary/secondary phase in the Local Authority. This data comes from the Ofsted management information for inspections of Initial Teacher Training.

The impact of the reforms and competition on student outcomes is measured using the national School Performance Tables. These record student performance on national standardized tests at the end of primary school (age 11) and at the end of secondary school (age 16). The primary school measure is the average points score, standardized by each school year. The secondary school measure is the best eight exam results across subjects for each student, averaged to the school-level, standardized by each school year.

\section{Results}

\section{a) Pay growth response}

The impact of the reform and local wages on the growth of teacher pay is found in Panel A of Table 3. This is estimated separately for primary schools (column 1) and secondary schools (column 2), because the size and relevant labor markets differ for these schools. ${ }^{18}$ There is a clear positive wage effect from a school being in a high wage area after the reform. Primary

\footnotetext{
${ }_{18}$ Secondary school teachers have been found to be more geographically mobile (Boyd et al. 2005a, Boyd et al. 2005b, Barbeiri, 2011)
} 
schools in areas with a one-pound higher hourly median wage awarded 0.17 percentage points higher increases in teacher salaries. To put this in context, the difference between the $25^{\text {th }}$ and $75^{\text {th }}$ percentile in the local median wage distribution for primary schools is $£ 2.53$. This would result in primary teachers having 0.43 percent points higher than expected pay growth annually. For secondary schools, the equivalent change in percentiles would lead to a 0.37 percentage points higher than expected pay growth annually. This is consistent with the hypothesis that schools compete with non-schools for labor and react to local labor market conditions. ${ }^{19}$

Independent of affecting the average difference from pay growth rate, the reforms and competition may impact the variation in the growth of teacher pay within a school. Panel B of Table 3 shows the impact of the reform on the within-school variance in difference from expected pay progression. We see that there was an increase in the variability in teachers' pay awards in high competition areas for primary schools, but there was no impact on the dispersion of pay for secondary schools. This implies that even though secondary schools in high competition areas increase salaries at a higher rate following the reform, they are applying these increases to all staff similarly.

\section{b) Quantity of Teachers response}

Does increasing teacher pay in high pay labor markets lead to an increase or a decrease in the number of teachers employed? In the basic model of teacher pay scales, schools in both high and low wage areas will increase their employment. In our specification we estimate the relative change in employment for schools in high wage areas compared to low wage areas, where a positive coefficient implies that schools in high wage areas employ more teachers. It is theoretically ambiguous what sign this would have. A positive value means that schools in high wage areas changed more as a result of the increase in pay flexibility and therefore implies that the previous pay scales were closer to the market clearing rate in low wage areas.

Panel A of Table 4 shows that both primary and secondary schools in high wage areas employ relatively more full-time equivalent (FTE) teachers on the main pay scale after the

\footnotetext{
${ }^{19}$ Appendix Figure A.1 presents histograms of difference from expected growth for schools in highest and lowest quintile of non-teacher graduate wages areas. This shows that the distribution becomes more dispersed after the reforms, and schools in the high competition areas difference from expected growth becomes higher.
} 
reform compared to low wage areas. Using a FTE measure is a complete measure of labor supply to the school, including both the intensive and extensive labor supply. For every pound increase in median wages secondary schools take on 0.29 more teachers on the main pay scale (or existing teachers increase their contracted working hours). Given that there were no rules restricting the number of teachers a school could employ, this implies that the schools use the pay freedom to attract or retain more teachers in these competitive areas. The increase in the supply of teachers is considerably smaller, but remains positive and significant at 0.02 . The larger coefficient for secondary schools will in part reflect that they have seven times as many teachers on the main pay scale compared to primary schools.

The following panels of Table 4 decompose what is generating this relative increase in FTE in teachers by using alternate measures of teacher employment. Panel B uses a headcount for the number of teachers on the main pay scale. There is little change in the coefficient from panel A, implying that schools are employing more teachers rather than teachers working more hours. Panel $\mathrm{C}$ tests if these additional teachers are new to the school, by replacing the dependent variable with the number of teachers newly employed within the last year. We find that neither primary nor secondary schools in high wage areas increase the number new teachers on the main pay scale as a result of the reform. For secondary schools in high competition areas there is a significant relative reduction in the number of new hires. This, taken in conjunction with schools employing more teachers, implies that schools are using these higher wages to retain existing teachers.

The final panel of Table 4 shows the total impact on the deployment of the budget from these increases in salary and retaining more teachers. The dependent variable is total salary spending on main pay scale teachers. For primary schools we find that as local hourly wages increase by $£ 1$, the spending on main pay scale teachers increases by $£ 2,237$. For secondary schools, which are larger and have a larger increase in employment, this figure is $£ 11,788$.

\section{c) Pupil Performance}

The ultimate goal of the reform was to improve student test scores, through the introduction of performance-based pay rather than the rigid pay scales. Both primary and secondary schools in competitive labor markets reacted to this increased pay flexibility by raising pay growth and retaining relatively more teachers. These changes occurred from 2014, 
as this is the first year that pay could be impacted, however the reform started in 2013. Given that teachers future pay became dependent on performance from 2013, we allow for the impact on student achievement to occur from 2013, rather than 2014 as with the previous analysis. Table 5 presents the causal estimates of how student performance in national examinations from schools in more competitive labor markets changed as a result of the reform. For primary schools we see that as local wages increase by $£ 1$ student test scores increase by 1.4 percent of a standard deviation. To scale the size of this effect, a primary school at the 75th percentile of local wages increased their increases student test scores by 3.5 percent of a standard deviation more than a school at the 25 th as a result of the reform. For secondary schools there is a larger impact, for each $£ 1$ increase in hourly wages student performance increases by 3.3 percent of a standard deviation..$^{20}$ As these increases in student performance occur before any changes to teacher salary or supply, we infer that they are caused by increased teacher effort in these high wage areas.

\section{Robustness}

\section{a. Alternate Samples}

This section establishes the robustness of our results by estimating the effects for different samples. Table 6 shows the robustness of these results for different samples. Panel A shows the impact on Primary Schools and Panel B for Secondary Schools. The first column represents our main estimates on mean difference from expected pay progression.

The second column expands the sample to include schools that have missing data on teacher pay outcomes or teacher quantity outcomes in some years. The third column expands the sample again to include schools that have missing data on student performance in some years. Changing the sample to include these additional schools does not significantly change the estimates. The fourth column excludes 2013, the year before the reforms affected teachers' pay progression. We exclude this because even though the impacts on pay should not have been observed until 2014, the reforms were implemented in 2013. Again, there is no significant impact on either parameter. impact the estimates of the reform on teacher pay.

\footnotetext{
${ }^{20}$ Using the same treatment periods as the other specifications (2014 onwards) does not impact the primary school coefficient, but reduces the secondary school impact to 1.2 standard deviations. Figure 3 shows the event figures for these effects.
} 
One may be concerned that London is driving the results as it has a large number of Local Authorities, has the highest outside wages and had a different initial pay scale. Column 5 therefore re-estimates the main parameters excluding London. The primary school coefficient remains positive and significant, although reduces slightly from 0.17 to 0.13 , implying that primary schools in London responded more in terms of mean wage than schools from the rest of the country. For secondary schools, with the exclusion of London the impact on wages is no longer significant, suggesting that despite higher pay scales in London before the reforms, these schools had the strongest response to the reforms.

The main analysis uses only teachers on the main pay scale as we can accurately predict their expected wage growth. Column 6 in Table 6 presents estimates when we include all teachers (on the main and upper pay scales). The coefficients remain positive and significant, but are reduced in magnitude. This is expected given the additional measurement error associated with our derived difference from expected pay measure for these new teachers. ${ }^{21}$ The final column of Table 6 restricts the sample to teachers below the top of the main pay scale, as teachers at the top of the scale were subject to performance metrics to progress to the upper pay scale before the reforms. The results for the mean difference from expected progression are robust to this change.

\section{b. Alternate Competition Measures}

Our main analysis is estimating the response to the reform by local wage conditions. We now use a range of other local characteristics that impact the competition for teachers. Each column of Table 7 presents coefficients from separate regressions using different competition measures, the first being our main competition measure. The second column interacts the post reform indicator with our measure of teacher labor market tightness. We find that the reforms lead to schools in tighter labor markets increasing their wages more than schools in labor markets where there are many part-time or temporary teachers. A one standard deviation increase increases annual pay growth by 0.12 percentage points in primary schools. Another measure of tightness is the density of private schools. Column three shows that post reform schools in areas with many private schools increase their wages faster. In contrast the fourth

\footnotetext{
${ }^{21}$ Appendix Table A.2 repeats this analysis for secondary schools. We again find no large differences to the estimates when changing the sample used.
} 
column interacts the reform with the presence of teacher trainer providers, a factor that would increase the supply of teachers. Consistent with our hypothesis of schools reacting to the local labor market, after the reform schools with a higher supply of new teachers had 0.29 percent lower pay increases. For secondary schools the coefficient is negative but not significant.

These labor market factors are not necessarily independent, there is likely a correlation between local wages and labor market tightness. Therefore, column 5 includes all the factors simultaneously, the coefficients keep their original sign but some lose their significance. For primary schools we continue to find the positive effect of local wages, and a negative effect of teacher supply on teacher wage growth. These coefficients are very similar to their original coefficients, implying that they are having independent impact on teacher wages. For secondary schools the local wages remain important, but for this group of schools the density of private schools additionally impacts wages. We interpret this positive independent effect on wages from the presence of private schools as the competition for teachers between the sectors.

\section{c. Common Trends}

Finally, we test for differential pre-trends in high and low wage areas. Figure 4 presents four event diagrams of the differential effects in the years before and after the reform, for primary and secondary schools for the following outcomes; 1) Additional Pay Growth; 2) FTE Teachers employed; 3) Total Spending on Teachers; and 4) Student Performance. If the common trends assumption holds then we should expect to see no significant differences before the reform. The reforms were implemented in 2013, and the first year that they could impact teacher pay is in 2014, we therefore use 2012 as the reference year for all specifications.

In Panel $\mathrm{A}$ of Figure 4 we see that the difference from expected pay growth was not correlated with outside wages in the years prior to 2014. From this year, the first that teacher pay could be effects, teachers in high wage areas experienced relatively higher wage growth. This growth is concentrated in the first year of the reform and then decreases. As the outcome is percentage points different from expected growth, any non-negative value following the large positive values in 2014 means that teachers in high wage areas are still being paid more.

Panels B \& C show that prior to the reform there was no differential growth in teacher numbers or spending on teachers prior to the reform. However, from 2014 we see that schools 
in high wage areas are spending more and employing more main pay scale teachers. These increases are larger for secondary schools which employ on average seven times as many main pay scale teachers as primary schools. Unlike the growth in pay, which decreases after the first year, there is no fall in teachers employed or the amount spent or teachers in 2015.

The final panel presents the event diagram for student performance. Here we see that there was an increase in student performance in 2013, the year before teacher salaries changed. As noted previously 2013 is the first year that teacher performance would determine future salary, therefore we should be unsurprised that student achievement increases. Note that this is also before the relative increase in the number of teachers, implying that that part of the increase in student test scores is due to improved teacher performance. Again, these gains are larger for secondary schools compared to primary schools.

\section{d. Heterogeneity}

Having established the robustness of the results to different samples and measures of the teacher labor market, we now estimate the heterogeneity of these effects by different school types. The reform was intended to give schools the pay freedoms that academy schools already enjoyed. One may assume that the academy schools would be unaffected by the reform as they did not have to follow the previous pay regulations. Columns 2 and 3 of Table 8 show the estimated impact for primary non-academies and academies separately. Indeed, we find that the main effect is driven by the response of non-academy primary schools. Primary academies do not significantly change their pay policies as a result of the reform and being in a competitive area.

We next split primary schools into thirds, defining the highest and lowest attaining according to their pre-reform student performance. For primary schools previously high attaining schools react more strongly to local wages after the reform, compares to low achieving schools with coefficients of 0.15 and 0.08 respectively. For secondary schools the situation is reverse with low performing secondary schools reacting more, with coefficients of 0.1 and 0.13 . For both school types the coefficients are not significantly different by prior attainment. 
The final two columns estimate the impact by the poverty status of the students. Here there is a more consistent pattern for primary and secondary schools, schools in the top third of the proportion of students in receipt of free school meals react more than schools in the bottom third. This is consistent with schools with the most disadvantaged students finding it more difficult to recruit and retain teachers and therefore have the most need to increase salaries.

Table 9 extends this heterogeneity analysis by estimating the impact on student test scores by student composition. Again, we find that the gains in student test scores due to the reform are increasing in the proportion of the school that is disadvantaged. Primary schools with the most disadvantaged students experience an increase in test scores of 1.6 percent of a standard deviation for every pound increase in local wages, whereas the comparative figure is 0.9 percent for schools with the least disadvantaged students. This is consistent with schools that were most constrained by pay regulation, schools in high wage areas with high proportion of disadvantaged students, made the largest changes and hence saw the largest improvements in productivity. ${ }^{22}$

We have focused on school reactions to the reform as schools set teachers' salaries. However, the characteristics of the teacher may also impact pay growth. One of the advantages of a fixed teacher pay scale is that it reduces the role of biases in the determination of wages. We now test if teachers' individual characteristics impact wage growth. In doing so we change the unit of observation from school-year to teacher year, with the parameter of interest being the characteristic interacted with a post reform indicator. We continue to include the interaction with local wages, but additionally include teacher gender, subject taught, ethnicity, and tenure at the school. The disadvantage of this method is that we cannot estimate the dispersion of wages only individual wage growth.

Table 10 presents estimates of the teacher characteristics interacted with post reform, for primary and secondary school teachers separately. We continue to find that the higher wages in the local labor market positively impacts salary growth. Secondary school teachers can

\footnotetext{
${ }^{22}$ Appendix Table A.4 repeats this analysis for secondary schools, where we find similar results. The reactions to local labor market conditions are driven by the non-academy secondary schools, with academies not significantly reacting to the reforms. Moreover, secondary schools with the most disadvantaged students react more to local wages in terms of salary growth.
} 
specialize in teaching Science, Engineering, Technology and Maths (STEM) subjects, which are typically harder to recruit. We find that these teachers do not experience a higher growth in wages compared to non-STEM teachers. In contrast, male primary school teachers experience 0.38 percentage points higher growth in salary compared to female teachers once decisions become decentralized to the headteacher. The coefficient for male secondary school teachers was also positive but not significant at standard levels. We find no differences across ethnicities after the reform, except for black secondary school teachers who gain 0.57 percentage point more post reform.

The largest differences by teacher characteristics is tenure at the school. The reference group are teachers that have been at the current school for less than two full academic years. Teachers with longer tenures at the school experience larger than expected growth in salaries compared to before the reform. Note, any general decline in salary growth is accounted for with the year effects, and any increase in pay due to the pre-existing pay scale has been accounted for. This is estimating the difference from expected growth relative to other schools in low wage areas in the same year. The finding that tenured teachers have higher than expected growth is consistent with more established teachers being able to influence the headteacher more by diverting effort away from the classroom in favor of politicking in order to get higher raises. It is also consistent with new teachers being paid above market rate before the reform.

\section{Conclusion}

We study the effects of the removal of pay rigidities in a public sector labor market. The reform entirely removed a bureaucratic system of national pay scales, under which individual teachers were being paid based on experience rather than productivity. In its place, schools were required to set pay individually, with regards to individual performance and their recruitment and retention needs.

We show that bureaucratic pay setting acted as a real constraint on schools in high wage areas. Post reform, schools in these areas award higher growth in teacher salaries and employ more teachers through higher retention rates. That schools in high wage areas employed relatively more teachers, means that the pre-existing pay scales imposed a wage that was further from the equilibrium level of employment compared to low wage areas. This is 
consistent with the state minimizing expenditures on teachers, subject to at least some markets clearing.

These results provide clear evidence that public sector pay scales have a negative impact on productivity. Once schools have the freedom to set salaries, schools in high competition areas experience significant gains in student achievement. The gains in student performance were largest in schools that were the most restrained by national pay scales, those in high wage labor markets with high proportions of disadvantaged students. The reduced form effect on pupil attainment is a combination of the effect of the reforms on teacher quality, teacher effort, teacher retention, and schools' optimal resource spending. However, the existence of significant gains before teacher retention increased is strong evidence that much of these gains are due to increased teacher effort. The effects of this pay deregulation will continue to play out over the next few years, and as pupils graduate secondary school after completing all of their education under the new regime, we may expect to see greater effects on pupil achievement.

Taken together, the implications of our findings for the wider public sector are clear. Whilst there are well established theoretical benefits to having a defined pay-scale (some of which we find in the data, for example pay discrimination and nepotism), we find that there are net benefits from removing them. National pay scales prevent local managers from allocating resources efficiently. Given autonomy, organizations in high wage areas move away from the national pay scales in order to increase pay and pay dispersion. This has allowed them to retain experienced staff. Critically we find that productivity improves once these pay rigidities are removed. That much of the improvement occurs before the increases in teacher supply, implies that performance related pay systems increase observable outcomes. 


\section{References}

Bamford, S. and Worth, J. (2017). Teacher Retention and Turnover Research. Research Update 3: Is the Grass Greener Beyond Teaching? Slough: NFER.

Barbieri, G., Rossetti, C., Sestito, P. (2011) The determinants of teacher mobility: Evidence using Italian teachers' transfer applications" Economics of Education Review, 30, Issue 6,1430-1444

Boyd, D. Lankford, H., Loeb, S., Wyckoff, J. (2005) “The draw of home: How teachers' preferences for proximity disadvantage urban schools" Journal of Policy Analysis and Management, 24 (1) pp. 113-132

Boyd, D. Lankford, H., Loeb, S., Wyckoff, J. “Explaining the short careers of high-achieving teachers in schools with low-performing students" American Economic Review, 95 (2), pp. 166-171

Britton J. and Propper C. (2016) “Teacher pay and school productivity: Exploiting wage regulation" Journal of Public Economics 133: pp. 75-89

Buchan, J., \& Black, S. (2011). The Impact of Pay Increases on Nurses' Labour Market. A Review of Evidence from Four OECD Countries", OECD Health Working Papers, No. 57, OECD Publishing, Paris,https://doi.org/10.1787/5kg6jwn16tjd-en.

Burgess, S. and Ratto, M. (2003) 'The Role of Incentives in the Public Sector: Issues and Evidence'. Oxford Review of Economic Policy, Volume 19, Issue 2, 1 June 2003, Pages 285300

Burgess, S., Croxson B., Gregg, P., Propper C. (2001) ‘The Intricacies of the Relationship Between Pay and Performance for Teachers: Do teachers respond to Performance Related Pay schemes?' CMPO Working Paper Series No. 01/35

Department for Education (2012) “Evidence to the STRB: The Case for Change". London: DfE [online]. Available:

https://www.gov.uk/government/uploads/system/uploads/attachment data/file/192218/evidence to the strb the case for change.pdf [4 October, 2018]

Department for Education (2016) “Schools workforce in England 2010 to 2015: trends and geographical comparisons" London: DfE September 2016

Department for Education (2017) “Evalaution of Techers' Pay Reform” London: DfE November 2017

Department for Education (2018a) "Analysis of teacher supply, retention and mobility", London DfE, February 2018.

Department for Education (2018b) "Schools' costs: 2018-19 to 2019-20", London DfE, February 2018.

Department for Education (2018a) "School Workforce in England: November 2017", London DfE, June 2018. 
Department for Education (2018c) "Open academies and academy projects in development", Department for Education, August 2018.

https://www.gov.uk/government/publications/open-academies-and-academy-projects-indevelopment

Dixit, A. (2002) "Incentives and Organizations in the Public Sector: An Interpretative Review". The Journal of Human Resources Vol. 37, No. 4 (Autumn, 2002), pp. 696-727

Foster, D. (2018) "Teacher Recruitment and retention in England", House of Commons Library Briefing Paper, Number 7222, June 2018.

Green, F., Machin, S., Murphy, R. \& Zhu, Y. (2008) “Competition for private and state school teachers" Journal of Education and Work, 21:5, 383-404

Greaves, E. \& Sibieta, S. (2014) "Estimating the effect of teacher pay on pupil attainment using boundary discontinuities", IFS Working Paper W14/03.

https://www.ifs.org.uk/publications/7125

Grimshaw, D. (2000). The problem with pay flexibility: changing pay practices in the UK health sector. International Journal of Human Resource Management, 11(5), 943-966.

Kessler, I. (1990). Flexibility and comparability in pay determination for professional civil servants. Industrial Relations Journal, 21(3), 194-208.

Office of National Statistics, ONS (2016a) “Internal migration, England and Wales: Year Ending June 2015", Statistical bulletin, 23 June 2016, Available At:

https://www.ons.gov.uk/peoplepopulationandcommunity/populationandmigration/migrati onwithintheuk/bulletins/internalmigrationbylocalauthoritiesinenglandandwales/yearending june2015

Office of National Statistics ONS (2016b) "Population of Local Authorities", Freedom of Information Request. Available at:

https://www.ons.gov.uk/aboutus/transparencyandgovernance/freedomofinformationfoi/populatio noflocalauthorities

Propper C. and Van Reenen, J. (2010) "Can Pay Regulation Kill? Panel Data Evidence on the Effect of Labor Markets on Hospital Performance" Journal of Political Economy 118, no. 2 (April 2010): 222-273.

Söderström, M. (2006). "Evaluating Institutional Changes in Education and Wage Policy" IFAU Dissertation Series 2006:3.

Woessmann, L. (2011) "Cross-country evidence on teacher performance pay" Economics of Education Review, Volume 30, Issue 3: 404-418

Willén Alexander L.P. (2019) "From a Fixed National Pay Scale to Individual Wage Bargaining: The Labor Market Effects of Wage Decentralization" IFAU Working Paper No. 2019:17 
Figure 1 Removal of National Pay Scale

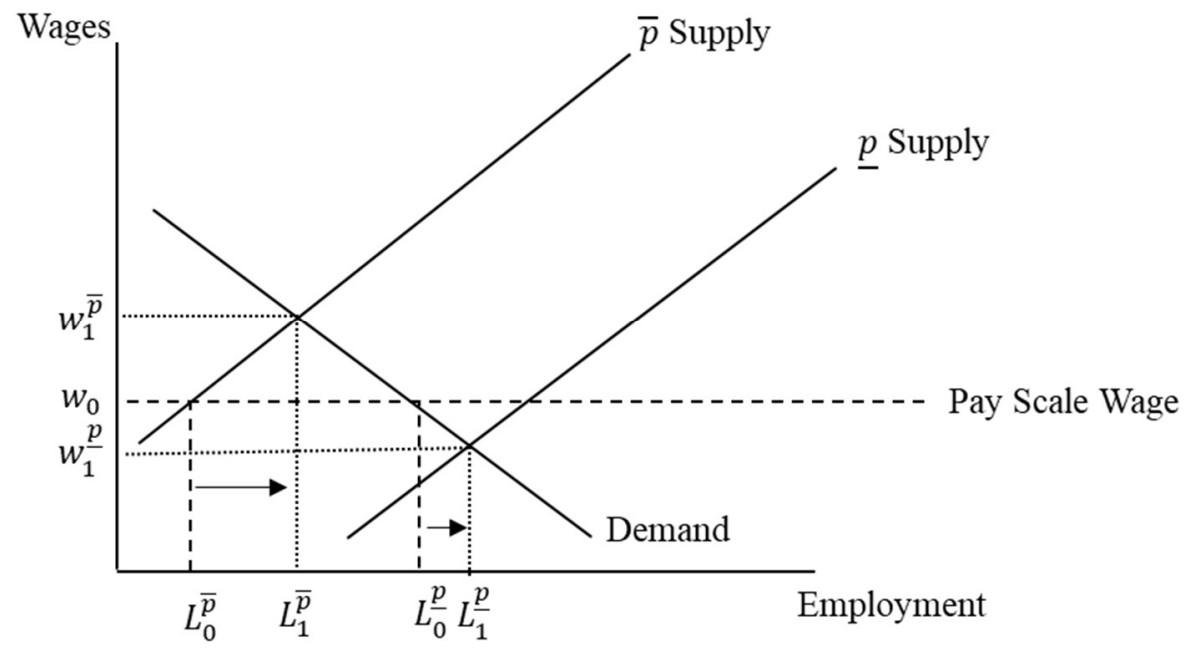

Notes: This represents the removal of a national pay scale on wages $(w)$ and labor demanded $(L)$ in high $(\bar{p})$ and low productivity regions $(\underline{p})$. For $\bar{p}: w_{0}$ to $w_{1}^{\bar{p}}$ and $L_{0}^{\bar{p}}$ to $L_{1}^{\bar{p}}$. For $\underline{p}: w_{0}$ to $w_{1}^{\underline{p}}$ and $L_{0}^{\underline{p}}$ to $L_{1}^{\underline{p}}$.

\section{Figure 2 Variation in the Difference from Expected Grow for Non-London Teachers}

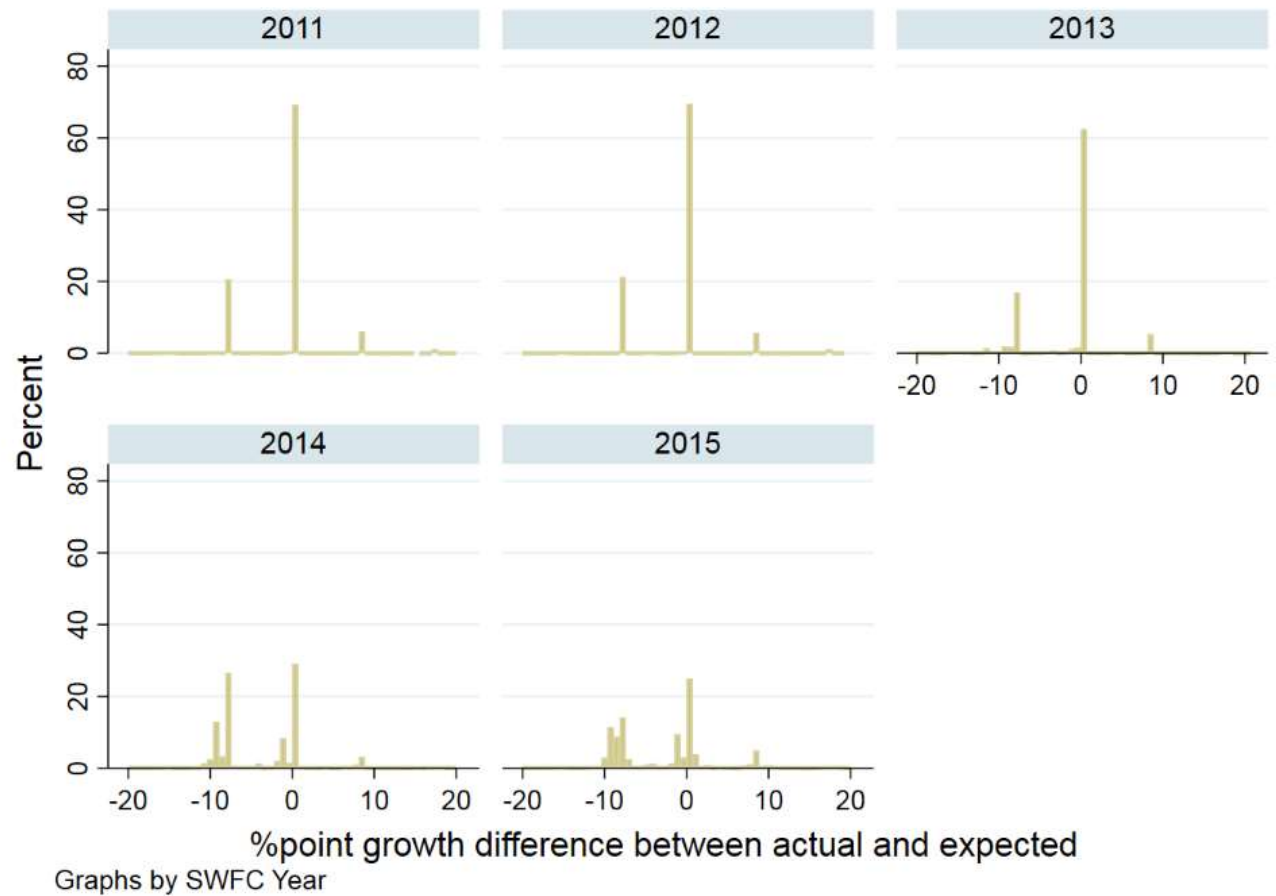

Note: ' 0 ' represents that the annual pay increase was equal to 'expected progression' under the system of automatic progression. The sample selection is all teachers in pay region outside London ('the rest of England and Wales') on the main pay range, below the top of the main pay range so that pay progression is possible without promotion to the upper pay range. 
Figure 3 Measures of Teacher Demand by Local Authority

Panel A: Median Hourly Wages (2011)

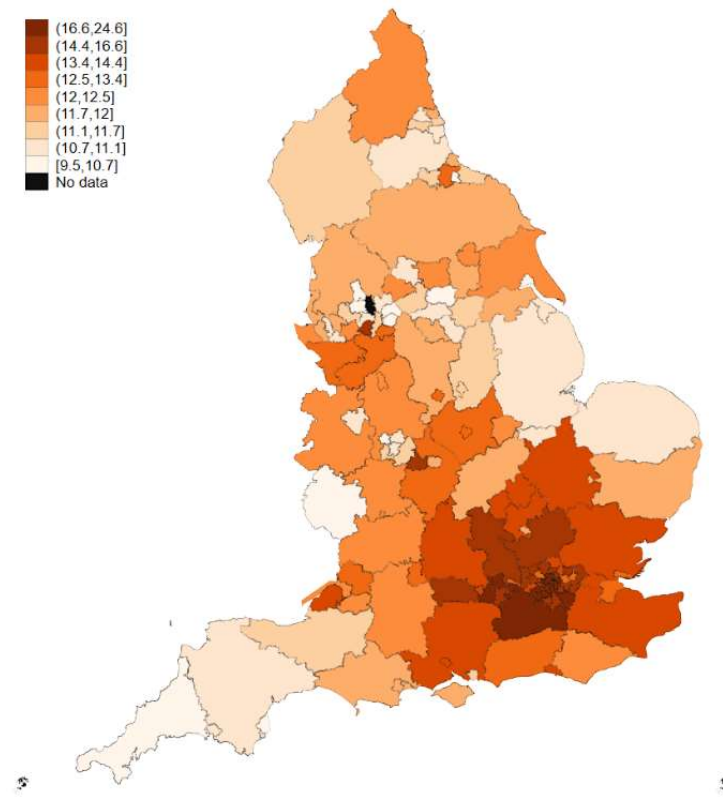

Panel C: Private school density

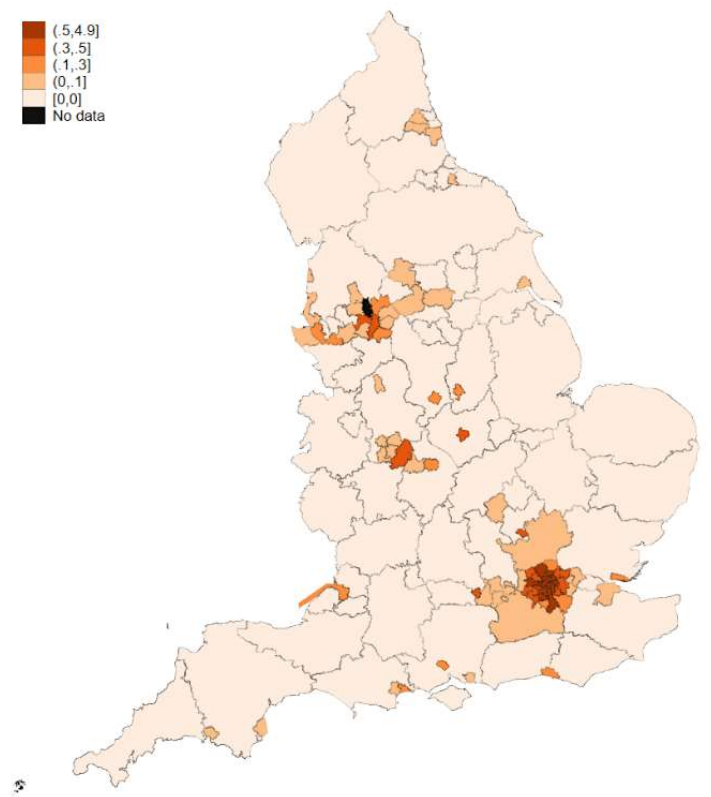

Panel B: Tightness index
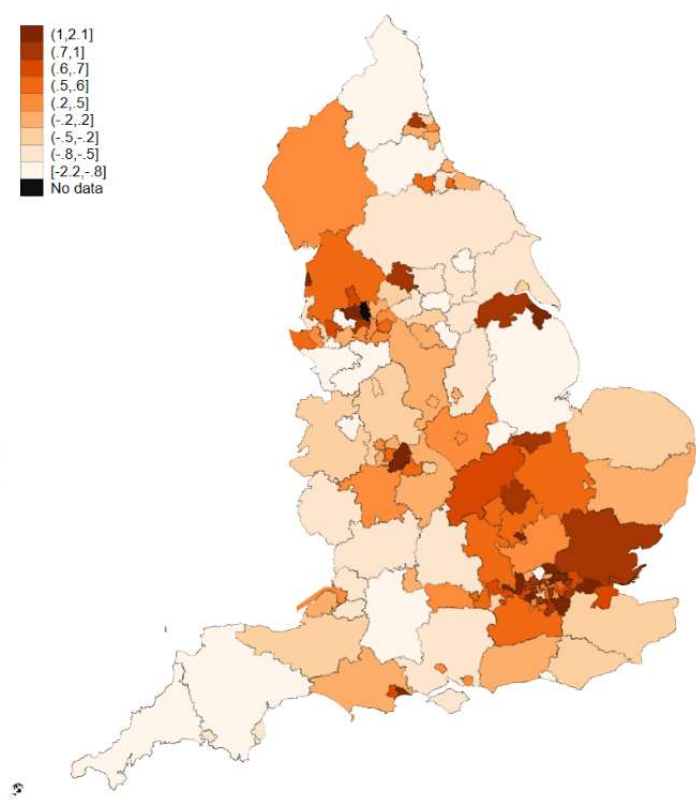

Panel D: Teacher Training Provision

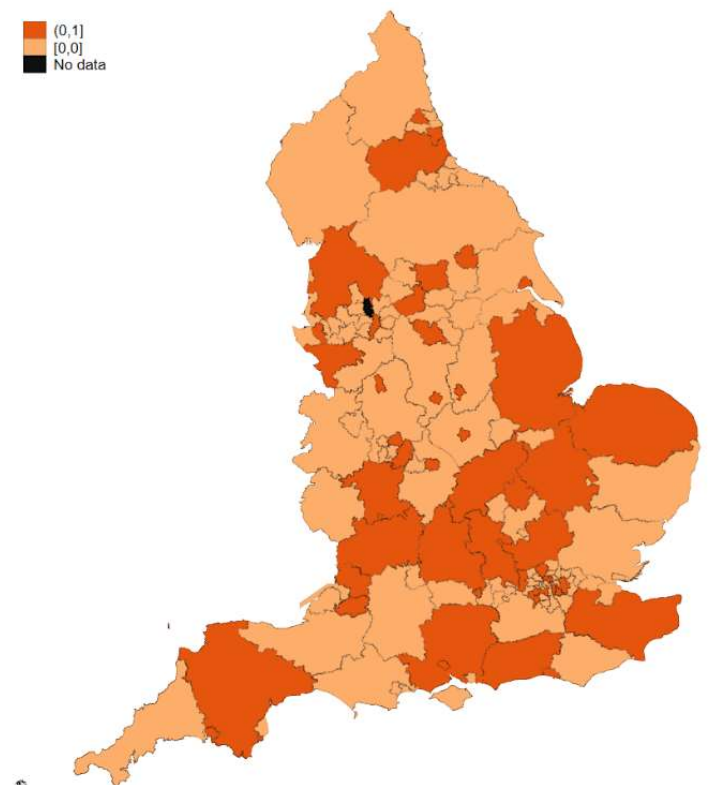

Source; Panel A - Median hourly wage of non-teacher graduates - Annual Survey of Hours and Earnings; Panel B - Number of Schools of the same education stage within $3 \mathrm{~km}$. Separate measures for primary and secondary schools are averaged to the LA level - School Workforce Census; Panel C: Local Authority density of private schools - School-level Census; Panel D - Source: Ofsted management information for inspections of Initial Teacher Training provision. Note: " 1 " indicates there is a Higher Education Institution that delivers Initial Teacher Training for the primary phase in the Local Authority. 
Figure 4 Impact of Reform by Local Wages

A) Difference from Expected Pay Growth

B) Total Main Pay Scale Teachers (FTE)
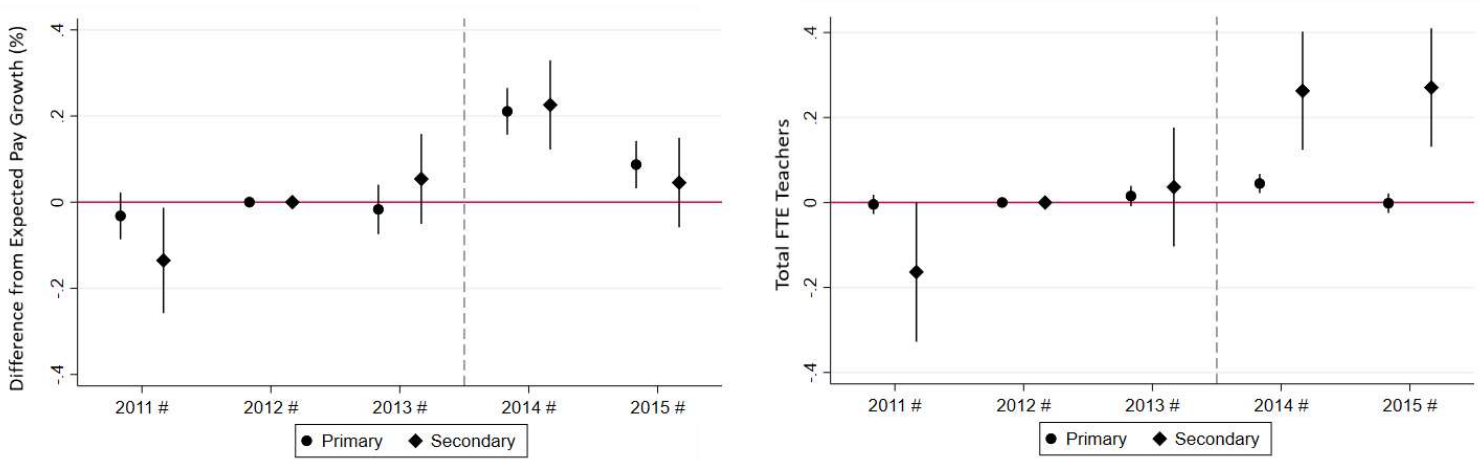

C) Spending on Teachers

D) Standardized Test scores
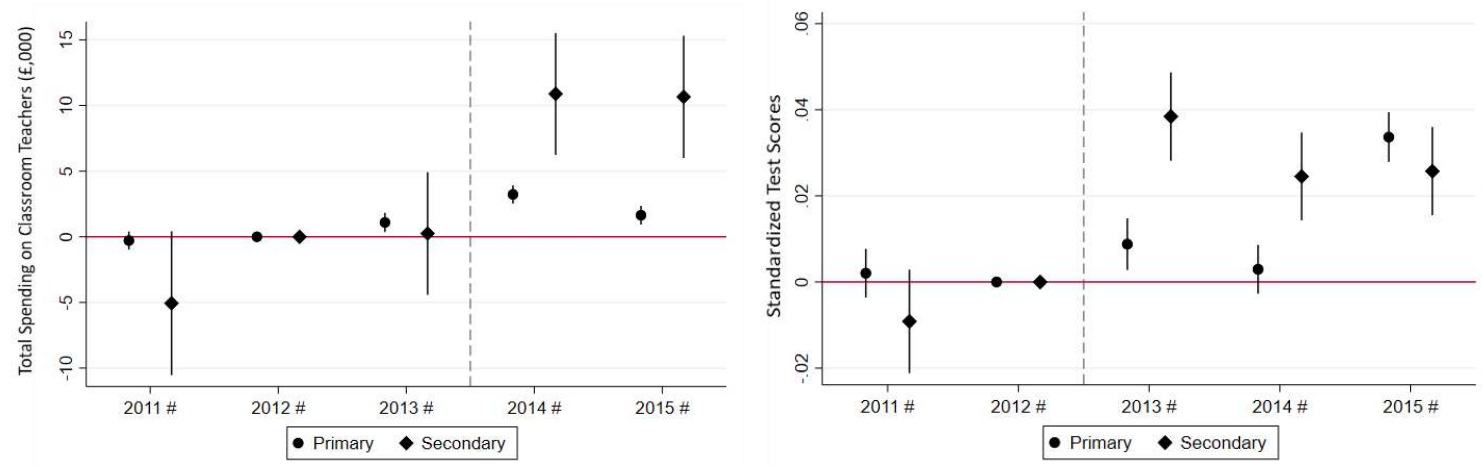

Source: School Workforce Census, School-Level Census, ASHE.

Note: Figure shows estimates four separate estimations. All specifications include year and school fixed effects. The dashed line indicates the first year that we allow the reform to impact the outcome in the main specification. Standard errors clustered at the school level, showing 95 percent confidence intervals. 
Table 1: Main pay scale for classroom teachers in 2012

\begin{tabular}{ccccc}
\hline \hline Scale & England & Inner & Outer & Fringe \\
Point & $\&$ Wales & London & London & Area \\
\hline 1 & $£ 21,588$ & $£ 27,000$ & $£ 25,117$ & $£ 22,626$ \\
2 & $£ 23,295$ & $£ 28,408$ & $£ 26,674$ & $£ 24,331$ \\
3 & $£ 25,168$ & $£ 29,889$ & $£ 28,325$ & $£ 26,203$ \\
4 & $£ 27,104$ & $£ 31,446$ & $£ 30,080$ & $£ 28,146$ \\
5 & $£ 29,240$ & $£ 33,865$ & $£ 32,630$ & $£ 30,278$ \\
6 & $£ 31,552$ & $£ 36,387$ & $£ 35,116$ & $£ 32,588$ \\
\hline \hline
\end{tabular}

Source: School Teachers' Pay and Conditions Document (2012). Notes: Scale points represent teachers' years of experience as a teacher. England $\&$ Wales region excludes London and surrounding areas. 
Table 2 Summary Statistics

\begin{tabular}{|c|c|c|c|c|c|}
\hline & 2011 & 2012 & 2013 & 2014 & 2015 \\
\hline \multicolumn{6}{|l|}{ Panel A: Teacher-level } \\
\hline Male & 0.21 & 0.23 & 0.24 & 0.23 & 0.23 \\
\hline White British & 0.86 & 0.85 & 0.84 & 0.85 & 0.84 \\
\hline Newly Qualified Teacher & 0.2 & 0.24 & 0.26 & 0.27 & 0.26 \\
\hline Age & 32.22 & 31.86 & 31.67 & 32.06 & 32.03 \\
\hline Salary & 28.14 & 27.95 & 28.11 & 28.33 & 28.6 \\
\hline Annual Salary Growth \% & 8.42 & 6.26 & 7 & 7.28 & 7.14 \\
\hline Growth According to Pay Scale & 0.61 & 0.61 & 0.58 & 0.36 & 0.42 \\
\hline Actual - Predicted Annual Salary Growth & -2.6 & -2.5 & -2.73 & -4.04 & -2.86 \\
\hline \multicolumn{6}{|l|}{ Panel B- School-level } \\
\hline Mean Difference From Expected Growth & -2.74 & -2.58 & -2.78 & -4.21 & -3.13 \\
\hline S.D. Difference From Expected Growth & 4.03 & 4.11 & 4.75 & 4.3 & 5.07 \\
\hline Local Median Hourly Wage & 12.74 & 12.81 & 12.89 & 12.75 & 12.72 \\
\hline Expenditure Classroom Teachers $(£, 000)$ & 232.28 & 324.14 & 329.31 & 247.54 & 271.49 \\
\hline Teachers on Main Pay Range & 8.61 & 12 & 11.96 & 9.07 & 9.91 \\
\hline Teachers on Main and Upper Pay Ranges & 18.82 & 27.23 & 26.66 & 18.02 & 19.94 \\
\hline Proportion New Teachers & 0.12 & 0.17 & 0.2 & 0.21 & 0.23 \\
\hline Teacher Labor Market & -0.93 & -0.66 & -0.55 & -0.96 & -0.77 \\
\hline Private School Density & 0.16 & 0.16 & 0.22 & 0.16 & 0.16 \\
\hline Primary Teacher Training Institution & 0.45 & 0.44 & 0.46 & 0.44 & 0.47 \\
\hline Secondary Teacher Training Institution & 0.46 & 0.44 & 0.47 & 0.44 & 0.47 \\
\hline Primary school & 0.86 & 0.72 & 0.75 & 0.86 & 0.83 \\
\hline Academy school & 0 & 0.20 & 0.28 & 0.28 & 0.28 \\
\hline
\end{tabular}

Sources: School Workforce Census, Edubase, School Census, Ofsted management information for Initial Teacher Training, 2010-2015, Annual Survey of Hours and Earnings 2011,. 2010 is excluded as the common sample definition excludes those were the difference from expected progression is missing, which can't be defined in the first year of the School Workforce Census. Notes: Newly Qualified Teacher is defined as observed in the School Workforce Census for the first time. 
Table 3 Impact Pay Growth

\begin{tabular}{lcc}
\hline & $\begin{array}{c}\text { Primary } \\
(1)\end{array}$ & $\begin{array}{c}\text { Secondary } \\
(2)\end{array}$ \\
\hline Panel A: Mean Difference from Expected Growth \\
\hline Post X Local Wages & $0.168^{* * *}$ & $0.144^{* * *}$ \\
& $(0.018)$ & $(0.035)$ \\
Constant & $-2.559^{* * *}$ & $-2.165^{* * *}$ \\
& $(0.041)$ & $(0.099)$ \\
\hline Panel B: Variance of Difference from Expected Growth \\
\hline Post X Local Wages & $0.049^{* * *}$ & -0.026 \\
& $(0.015)$ & $(0.023)$ \\
Constant & $3.940^{* * *}$ & $4.520^{* * *}$ \\
& $(0.033)$ & $(0.063)$ \\
\hline Observations (school X year) & 51,481 & 12,480 \\
\hline Source: School Workforce Census, School-Level Census, ASHE. \\
Note: All specifications include year and school fixed effects. Standard \\
errors in parentheses, clustered at the school level. ${ }^{*}$ Significant at the \\
10\% level. ** Significant at the 5\% level. *** Significant at the 1\% level.
\end{tabular}


Table 4 Impact on Teacher Quantity

\begin{tabular}{|c|c|c|}
\hline & $\begin{array}{c}\text { Primary } \\
(1)\end{array}$ & $\begin{array}{c}\text { Secondary } \\
(2) \\
\end{array}$ \\
\hline \multicolumn{3}{|l|}{ Panel A: Number of FTE Teachers } \\
\hline Post X Local Wages & $\begin{array}{l}0.019^{*} \\
(0.008)\end{array}$ & $\begin{array}{c}0.288^{* * *} \\
(0.047)\end{array}$ \\
\hline Constant & $\begin{array}{c}5.738^{* * *} \\
(0.017)\end{array}$ & $\begin{array}{c}23.785^{* * *} \\
(0.132)\end{array}$ \\
\hline \multicolumn{3}{|l|}{ Panel B: Number of Teachers } \\
\hline Post X Local Wages & $\begin{array}{c}0.033^{* * *} \\
(0.008)\end{array}$ & $\begin{array}{c}0.301^{* * *} \\
(0.049)\end{array}$ \\
\hline Constant & $\begin{array}{c}6.243^{* * *} \\
(0.018)\end{array}$ & $\begin{array}{c}24.754^{* * *} \\
(0.138)\end{array}$ \\
\hline \multicolumn{3}{|l|}{ Panel B: Proportion of Recent Hires } \\
\hline Post X Local Wages & $\begin{array}{c}0.001 \\
(0.001)\end{array}$ & $\begin{array}{c}-0.002^{* *} \\
(0.001)\end{array}$ \\
\hline Constant & $\begin{array}{c}0.128^{* * *} \\
(0.001) \\
\end{array}$ & $\begin{array}{c}0.105^{* * *} \\
(0.002) \\
\end{array}$ \\
\hline \multicolumn{3}{|c|}{ Panel D: Total Spending on Main Pay Scale FTE Teachers } \\
\hline Post X Local Wages & $\begin{array}{c}2.237^{* * *} \\
(0.234)\end{array}$ & $\begin{array}{c}11.788^{* * *} \\
(1.577)\end{array}$ \\
\hline Constant & $\begin{array}{c}166.645^{* * *} \\
(0.522) \\
\end{array}$ & $\begin{array}{c}688.946^{* * *} \\
(4.409) \\
\end{array}$ \\
\hline Observations (school $\mathrm{X}$ year) & 51,481 & 12,480 \\
\hline \multicolumn{3}{|c|}{$\begin{array}{l}\text { Source: School Workforce Census, School-Level Census, ASHE. } \\
\text { Note: All specifications include year and school fixed effects. Standard } \\
\text { errors in parentheses, clustered at the school level * Significant at the } \\
10 \% \text { level. ** Significant at the } 5 \% \text { level. }{ }^{* * *} \text { Significant at the } 1 \% \text { level. } \\
\text { on Pupil Performance }\end{array}$} \\
\hline & $\begin{array}{c}\text { Primary } \\
(1)\end{array}$ & $\begin{array}{c}\text { Secondary } \\
(2) \\
\end{array}$ \\
\hline Post X Local Wages & $\begin{array}{c}0.014^{* * *} \\
(0.002)\end{array}$ & $\begin{array}{c}0.033^{* * *} \\
(0.004)\end{array}$ \\
\hline Constant & $\begin{array}{l}-0.007 \\
(0.004) \\
\end{array}$ & $\begin{array}{c}0.048^{* * *} \\
(0.010)\end{array}$ \\
\hline Observations (school $\mathrm{X}$ year) & 51,481 & 12,480 \\
\hline
\end{tabular}

Source: School Workforce Census, School-Level Census, ASHE.

Note: All specifications include year and school fixed effects. Standard errors in parentheses, clustered at the school level. * Significant at the $10 \%$ level. ${ }^{* *}$ Significant at the $5 \%$ level. ${ }^{* *}$ Significant at the $1 \%$ level. 
Table 6 Robustness to Alternate Samples

\begin{tabular}{|c|c|c|c|c|c|c|c|}
\hline & $\begin{array}{l}\text { Main } \\
\text { Sample } \\
\text { (1) }\end{array}$ & $\begin{array}{c}\text { Less } \\
\text { Restrictive } \\
\text { Common } \\
\text { Sample } \\
(2)\end{array}$ & $\begin{array}{c}\text { All } \\
\text { Schools }\end{array}$ & $\begin{array}{c}\text { Exclude } \\
2013\end{array}$ & $\begin{array}{l}\text { Exclude } \\
\text { London }\end{array}$ & $\begin{array}{c}\text { All } \\
\text { Teachers }\end{array}$ & $\begin{array}{c}\text { Below } \\
\text { Top of } \\
\text { Spinepoint } \\
\text { (7) }\end{array}$ \\
\hline \multicolumn{8}{|c|}{ Panel A: Primary Schools } \\
\hline Post X Local Wages & $\begin{array}{c}0.168^{* * *} \\
(0.018)\end{array}$ & $\begin{array}{c}0.161^{* * *} \\
(0.017)\end{array}$ & $\begin{array}{c}0.162^{* * *} \\
(0.017)\end{array}$ & $\begin{array}{c}0.169^{* * *} \\
(0.020)\end{array}$ & $\begin{array}{c}0.131^{* * *} \\
(0.026)\end{array}$ & $\begin{array}{c}0.093^{* * *} \\
(0.012)\end{array}$ & $\begin{array}{c}0.148^{* * *} \\
(0.021)\end{array}$ \\
\hline Constant & $\begin{array}{c}-2.559^{* * *} \\
(0.041)\end{array}$ & $\begin{array}{c}-2.557^{* * *} \\
(0.038) \\
\end{array}$ & $\begin{array}{c}-2.606^{* * *} \\
(0.037) \\
\end{array}$ & $\begin{array}{c}-2.584^{* * *} \\
(0.041) \\
\end{array}$ & $\begin{array}{c}-2.517^{* * *} \\
(0.043) \\
\end{array}$ & $\begin{array}{c}-2.034^{* * *} \\
(0.025) \\
\end{array}$ & $\begin{array}{c}-0.951^{* * *} \\
(0.051) \\
\end{array}$ \\
\hline Observations & 51,481 & 58,322 & 65,528 & 43,654 & 44,055 & 60,297 & 43,015 \\
\hline \multicolumn{8}{|c|}{ Panel B: Secondary Schools } \\
\hline Post $X$ Local Wages & $\begin{array}{c}0.144^{* * *} \\
(0.035)\end{array}$ & $\begin{array}{c}0.137^{* * *} \\
(0.035)\end{array}$ & $\begin{array}{c}0.137^{* * *} \\
(0.033)\end{array}$ & $\begin{array}{c}0.187^{* * *} \\
(0.041)\end{array}$ & $\begin{array}{c}0.077 \\
(0.049)\end{array}$ & $\begin{array}{l}0.056^{*} \\
(0.024)\end{array}$ & $\begin{array}{c}0.130^{* * *} \\
(0.037)\end{array}$ \\
\hline Constant & $\begin{array}{c}-2.165^{* * *} \\
(0.099)\end{array}$ & $\begin{array}{c}-2.171^{* * *} \\
(0.098)\end{array}$ & $\begin{array}{c}-2.279^{* * *} \\
(0.074)\end{array}$ & $\begin{array}{c}-2.170^{* * *} \\
(0.100)\end{array}$ & $\begin{array}{c}-2.059^{* * *} \\
(0.103)\end{array}$ & $\begin{array}{c}-1.694^{* * *} \\
(0.067)\end{array}$ & $\begin{array}{c}-0.851^{* * *} \\
(0.105)\end{array}$ \\
\hline Observations & 12,480 & 12,624 & 14,305 & 9,764 & 10,698 & 12,651 & 12,295 \\
\hline
\end{tabular}

Source: School Workforce Census, School-Level Census, ASHE.

Note: All specifications include year and school fixed effects. Standard errors in parentheses, clustered at the school level. * Significant at the $10 \%$ level. ${ }^{* *}$ Significant at the $5 \%$ level. ${ }^{* * *}$ Significant at the $1 \%$ level. 
Table 7 Alternate Competition Measures: Mean Difference from Expected Growth

\begin{tabular}{lccccc}
\hline Panel A: Primary Schools & $(1)$ & $(2)$ & $(3)$ & $(4)$ & $(5)$ \\
\hline Post X Local Wages & $0.168^{* * *}$ & & & & $0.162^{* * *}$ \\
& $(0.018)$ & & & & $(0.023)$ \\
Post X Tight Labor Market & & $0.121^{* *}$ & & & -0.056 \\
& & $(0.045)$ & & & $(0.049)$ \\
Post X Density of Private Schools & & & $0.570^{* * *}$ & & 0.134 \\
& & & $(0.089)$ & & $(0.108)$ \\
Post X Teacher Training Center & & & & $-0.289^{* * *}$ & $-0.311^{* * *}$ \\
& & & & $(0.078)$ & $(0.080)$ \\
Constant & $-2.559^{* * *}$ & $-2.556^{* * *}$ & $-2.563^{* * *}$ & $-2.566^{* * *}$ & $-2.554^{* * *}$ \\
& $(0.041)$ & $(0.041)$ & $(0.041)$ & $(0.041)$ & $(0.041)$ \\
\hline Panel B: Secondary Schools & $(1)$ & $(2)$ & $(3)$ & $(4)$ & $(5)$ \\
\hline Post X Local Wages & $0.144^{* * *}$ & & & & $0.100^{*}$ \\
& $(0.035)$ & & & & $(0.042)$ \\
Post X Tight Labor Market & & -0.295 & & & -0.175 \\
& & $(0.162)$ & & & $(0.167)$ \\
Post X Density of Private Schools & & & $0.819^{* * *}$ & & $0.594^{* *}$ \\
& & & $(0.180)$ & & $(0.218)$ \\
Post X Teacher Training Center & & & & -0.037 & -0.078 \\
Constant & & & & $(0.143)$ & $(0.145)$ \\
& $-2.165^{* * *}$ & $-2.182^{* * *}$ & $-2.155^{* * *}$ & $-2.156^{* * *}$ & $-2.183^{* * *}$ \\
Observations (school X year) & $(0.099)$ & $(0.096)$ & $(0.099)$ & $(0.099)$ & $(0.096)$ \\
\hline Sour & 51,481 & 50,447 & 51,486 & 51,486 & 50,442 \\
\hline
\end{tabular}

Source: School Workforce Census, School-Level Census, ASHE.

Note: All specifications include year and school fixed effects. Standard errors in parentheses, clustered at the school level. * Significant at the $10 \%$ level. ${ }^{* *}$ Significant at the $5 \%$ level. ${ }^{* * *}$ Significant at the $1 \%$ level. 
Table 8 School Heterogeneity in Mean Difference from Expected Growth

\begin{tabular}{|c|c|c|c|c|c|c|c|}
\hline & $\begin{array}{c}\text { Primary } \\
\text { (1) }\end{array}$ & $\begin{array}{c}\text { Non- } \\
\text { Academy } \\
(2)\end{array}$ & $\begin{array}{c}\text { Academy } \\
(3)\end{array}$ & $\begin{array}{c}\text { Highest } \\
\text { attaining } \\
(4)\end{array}$ & $\begin{array}{c}\text { Lowest } \\
\text { attaining } \\
(5)\end{array}$ & $\begin{array}{c}\text { Highest } \\
\text { pupil } \\
\text { disadvantage } \\
\text { (6) }\end{array}$ & $\begin{array}{c}\text { Lowest pupil } \\
\text { disadvantage } \\
(7)\end{array}$ \\
\hline \multicolumn{8}{|c|}{ Panel A: Primary Schools } \\
\hline Post $X$ outside wages & $\begin{array}{c}0.168^{* * *} \\
(0.018)\end{array}$ & $\begin{array}{c}0.187^{* * *} \\
(0.020)\end{array}$ & $\begin{array}{c}0.066 \\
(0.052)\end{array}$ & $\begin{array}{c}0.156^{* * *} \\
(0.032)\end{array}$ & $\begin{array}{l}0.083^{*} \\
(0.040)\end{array}$ & $\begin{array}{c}0.171^{* * *} \\
(0.032)\end{array}$ & $\begin{array}{l}0.096^{* *} \\
(0.036)\end{array}$ \\
\hline Constant & $\begin{array}{c}-2.559^{* * *} \\
(0.041)\end{array}$ & $\begin{array}{c}-2.586^{* * *} \\
(0.044)\end{array}$ & $\begin{array}{c}-2.423^{* * *} \\
(0.109)\end{array}$ & $\begin{array}{c}-2.487^{* * *} \\
(0.088)\end{array}$ & $\begin{array}{c}-2.482^{* * *} \\
(0.084)\end{array}$ & $\begin{array}{c}-2.574^{* * *} \\
(0.089)\end{array}$ & $\begin{array}{c}-2.557^{* * *} \\
(0.085)\end{array}$ \\
\hline Observations & 51,481 & 42,496 & 8,985 & 11,854 & 12,420 & 12,012 & 11,890 \\
\hline \multicolumn{8}{|c|}{ Panel B: Secondary Schools } \\
\hline Post $X$ outside wages & $\begin{array}{c}0.144^{* * *} \\
(0.035)\end{array}$ & $\begin{array}{c}0.223^{* * *} \\
(0.054)\end{array}$ & $\begin{array}{c}0.085 \\
(0.047)\end{array}$ & $\begin{array}{c}0.098 \\
(0.054)\end{array}$ & $\begin{array}{c}0.136 \\
(0.075)\end{array}$ & $\begin{array}{c}0.266^{* * *} \\
(0.058)\end{array}$ & $\begin{array}{c}0.081 \\
(0.066)\end{array}$ \\
\hline Constant & $\begin{array}{c}-2.165^{* * *} \\
(0.033)\end{array}$ & $\begin{array}{c}-2.192^{* * *} \\
(0.035)\end{array}$ & $\begin{array}{c}-2.206^{* * *} \\
(0.087)\end{array}$ & $\begin{array}{c}-2.221^{* * *} \\
(0.069)\end{array}$ & $\begin{array}{c}-2.245^{* * *} \\
(0.067)\end{array}$ & $\begin{array}{c}-2.561^{* * *} \\
(0.067)\end{array}$ & $\begin{array}{c}-1.811^{* * *} \\
(0.070)\end{array}$ \\
\hline Observations & 12,480 & 5,435 & 7,045 & 3,836 & 4,126 & 3,935 & 3,907 \\
\hline
\end{tabular}

Source: School Workforce Census, School-Level Census, ASHE.

Note: All specifications include year and school fixed effects. Standard errors in parentheses, clustered at the school level. *

Significant at the $10 \%$ level. ${ }^{* *}$ Significant at the $5 \%$ level. ${ }^{* * *}$ Significant at the $1 \%$ level 
Table 9 Impact on Student Test Scores by School Composition

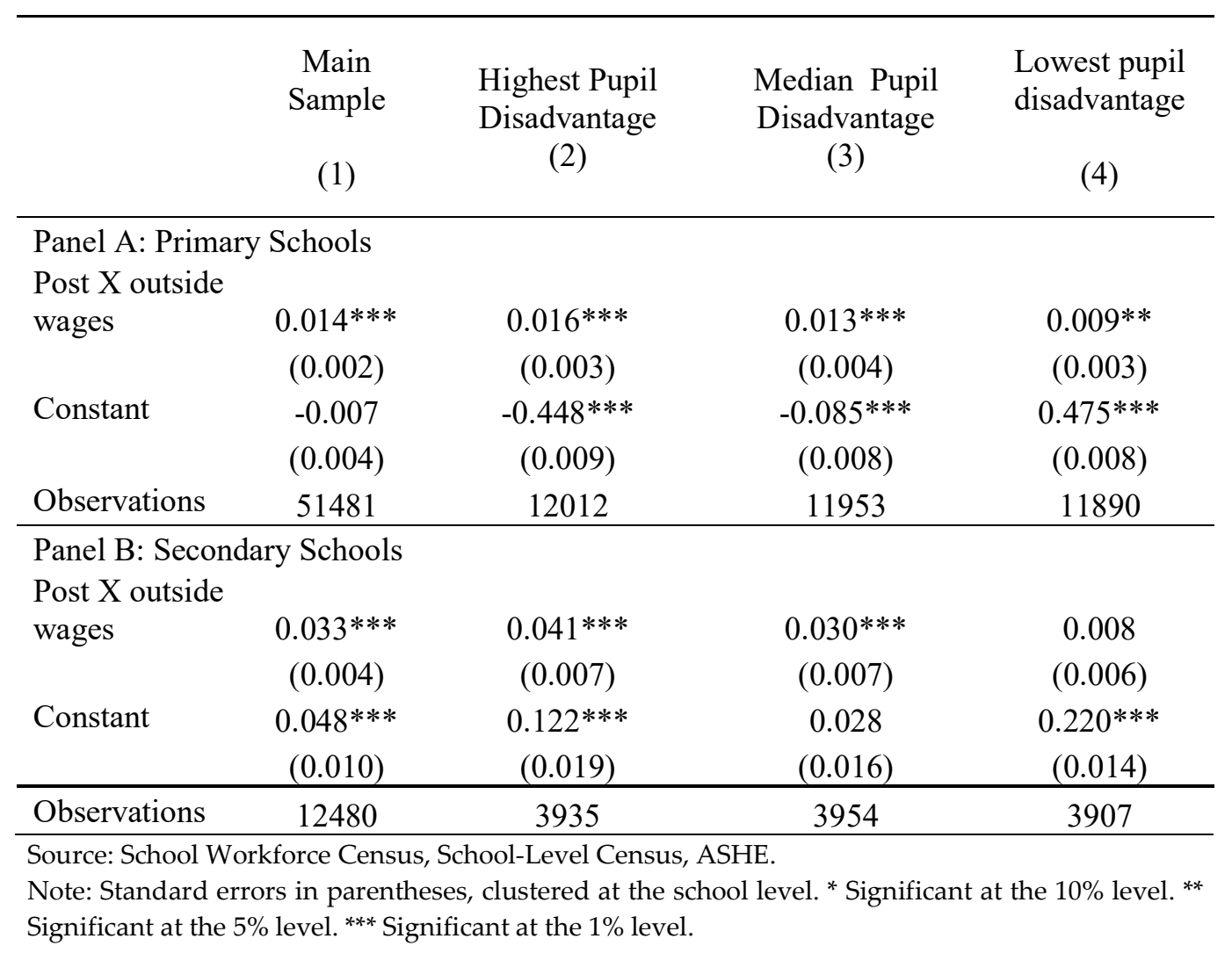


Table 10 Teacher Level Heterogeneity

\begin{tabular}{lcc}
\hline Mean Difference from Expected & Primary & Secondary \\
Growth & $(1)$ & $(2)$ \\
\hline Post X Local Wages & $0.119^{* * *}$ & $0.099^{* * *}$ \\
& $(0.011)$ & $(0.014)$ \\
Post X Majority STEM teaching & & 0.063 \\
& & $(0.058)$ \\
Post X Male & $0.373^{* * *}$ & 0.116 \\
& $(0.070)$ & $(0.060)$ \\
Post X Asian & -0.168 & 0.005 \\
& $(0.120)$ & $(0.124)$ \\
Post X Black & 0.280 & $0.574^{* *}$ \\
& $(0.191)$ & $(0.176)$ \\
Post X White Other & -0.089 & 0.169 \\
& $(0.117)$ & $(0.114)$ \\
Post X Any Other Ethnic Group & 0.100 & 0.091 \\
& $(0.182)$ & $(0.191)$ \\
Post X Tenure: 2-3 & $0.606^{* * *}$ & $0.434^{* * *}$ \\
Post X Tenure: 4-5 & $(0.061)$ & $(0.072)$ \\
Post X Tenure: 6-7 & $0.896^{* * *}$ & $0.926^{* * *}$ \\
Post X Tenure: 8+ & $(0.071)$ & $(0.081)$ \\
& $1.790^{* * *}$ & $2.510^{* * *}$ \\
Observations (teacher X year) & $(0.094)$ & $(0.113)$ \\
\hline Sour & $1.458^{* * *}$ & $2.629^{* * *}$ \\
& $(0.092)$ & $(0.141)$ \\
\hline
\end{tabular}

Source: School Workforce Census, School-Level Census, ASHE.

Note: All specifications include year and school fixed effects. Using Department for education ethnicity categories, White Other includes Irish, and other includes Mixed. Standard errors in parentheses, clustered at the school level. * Significant at the $10 \%$ level. ${ }^{* *}$ Significant at the $5 \%$ level. *** Significant at the $1 \%$ level. 
Appendix 1: Data cleaning

\subsection{Creating consistent school identifiers over time}

School identifiers can change over time, most commonly if a school changes status from LAmaintained to not LA-maintained (academy). This causes problems for the analysis, where one question of interest is whether the reforms led to changes in the mobility of teachers and leaders across schools. A "stable" identifier is therefore created, which in practice is the most recently recorded unique reference number (URN) in the linked data available through Edubase (accessed on 11/01/2016). This linked data records all known cases of "parent" and "child" schools, where the parent is typically the LA maintained school and child is typically the not LA-maintained school. Wherever a "child" is identified in the longitudinal SWC data the school identifier is replaced with the "parent", which leads to a stable identifier across the period.

\subsection{Cleaning full-time equivalent nominal base pay}

Full-time equivalent nominal base pay (referred to as base pay in this section) is observed for the majority of teachers and leaders in the longitudinal SWC. At the school level, $90 \%$ of schools have complete records of base pay for all teachers and leaders, rising to $96 \%$ once teachers and leaders paid a daily rate rather than base pay are excluded. There are problems observed with base pay where it is recorded, however. A number of steps have been taken to correct for clear cases of miscoding or mis-entry of base pay information. In turn, these steps are:

- Replace base pay with base pay/10 if the original value is large (above $£ 70,000$ for teachers and $£ 120,000$ for leaders) and the recoded variable is in line with adjacent values of base pay (within $18 \%)^{23}$.

- Replace base pay with missing if base pay is large (defined as above) and the original and recoded value (when divided by 10) is out of line with adjacent values (more than $18 \%$ difference).

\footnotetext{
${ }^{23}$ These cut-offs are based on the maximum growth across two spine points (around 18\%) and the maximum pay range for teachers and leaders in maintained schools, which were $£ 65,978$ in 2015/16 for leading practitioners (teachers) and $£ 114,437$ in 2015/16 for head teachers.
} 
- Replace base pay with missing if there are exceptionally large values, even if consistent with adjacent values. Exceptionally large values are defined as $£ 250,000$ for leaders and $£ 115,000$ for teachers.

- Replace base pay with missing where the hourly pay is equivalent to less than $£ 7$ per hour, which is less than the hourly rate for unqualified teachers in England.

- Replace base pay with missing where the hours worked per week are less than 0.33 hours per week. 
Appendix 2: Sample selection

The coding of base pay and growth variables described in Appendix 1 already implies some implicit selection to the final analysis sample. For example, those with exceptionally large or small values of base pay are excluded. Additional sample restrictions are:

- Include only schools classified as primary and secondary schools

- Exclude special schools, LA nursery schools, pupil referral units, studio schools and university technical colleges.

- Include only schools with more than $50 \%$ of (recoded) base pay observed.

- Include individuals aged 22 and above and 62 and below. These values correspond to the 1st and 99th percentile of the age distribution for teachers and leaders.

- Include individuals who work at least five hours per week and at least five weeks per year.

The impact of these sample restrictions on the final sample used for analysis is given in Appendix Table A.1 
Appendix Table A.1: Sample Selection

\begin{tabular}{|c|c|c|}
\hline Sample restriction (teachers) & N schools & $\mathrm{N}$ teachers ${ }^{*}$ years \\
\hline None & 22,234 & $2,529,811$ \\
\hline Non-missing base pay & 22,232 & $2,500,771$ \\
\hline Non-missing adjusted base pay & 22,231 & $2,486,712$ \\
\hline Primary and secondary schools only & 20,149 & $2,283,145$ \\
\hline $\begin{array}{l}\text { Exclude special schools, LA nursery schools, pupil referral } \\
\text { units, studio schools and university technical colleges }\end{array}$ & 20,076 & $2,281,189$ \\
\hline $\begin{array}{l}\text { Include only schools with more than } 50 \% \text { of (adjusted) base } \\
\text { pay observed }\end{array}$ & 19,911 & $2,261,190$ \\
\hline Include individuals aged 22 and above and 62 and below & 19,911 & $2,233,384$ \\
\hline $\begin{array}{l}\text { Include individuals who work at least } 5 \text { hours per week and } \\
\text { at least } 5 \text { weeks per year }\end{array}$ & 19,911 & $2,217,931$ \\
\hline Trim difference from expected progression & 19,911 & $2,153,237$ \\
\hline Drop schools that split between 2010-2015 & 19,901 & $2,132,762$ \\
\hline Main pay scale only & 19,817 & 941,222 \\
\hline Final common sample: & 16,610 & 652,737 \\
\hline School-level mean difference from expected progression & 19,586 & 782,894 \\
\hline $\begin{array}{l}\text { School-level standard deviation in difference from expected } \\
\text { progression }\end{array}$ & 18,638 & 761,381 \\
\hline Proportion of spending on teachers & 18,435 & 692,157 \\
\hline Total number of teachers on the main pay scale (FTE) & 18,435 & 692,157 \\
\hline Proportion of new teachers & 18,411 & 689,404 \\
\hline Test scores observed & 16,610 & 652,737 \\
\hline
\end{tabular}


Appendix Figure A.1 School Differences from Expected Pay Growth by Quintile of Local Wages
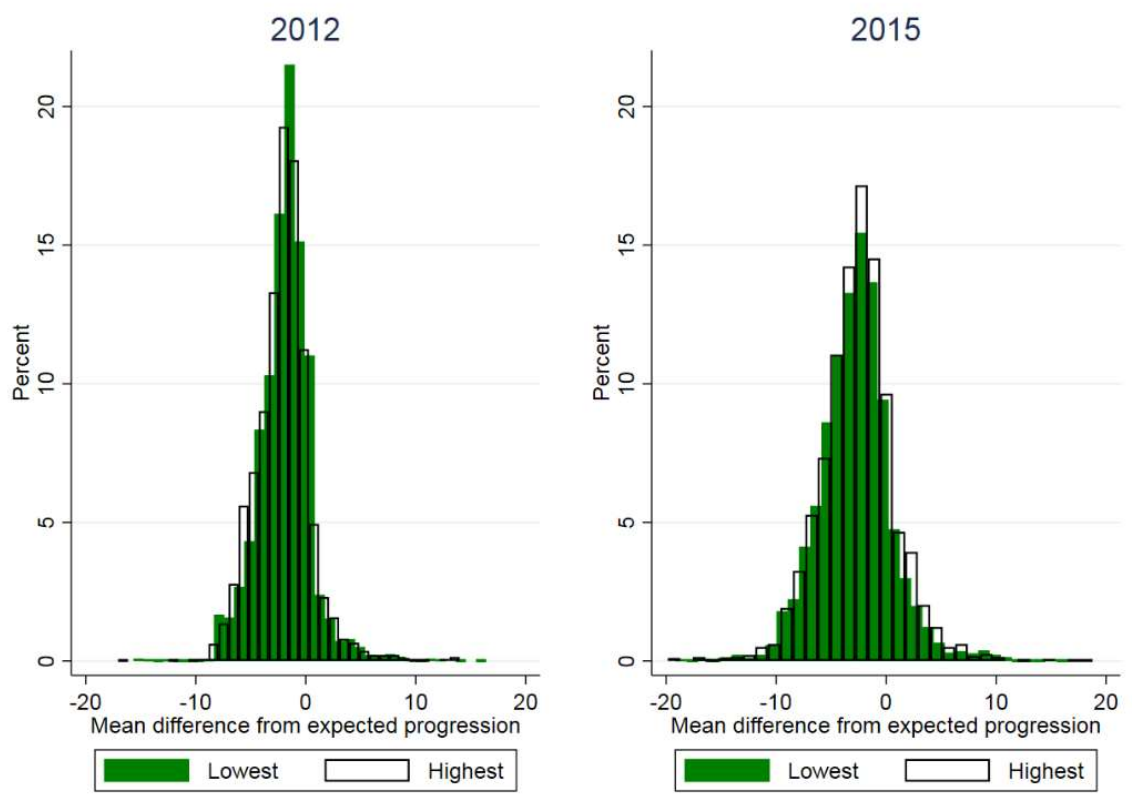

Source: School Workforce Census and Annual Survey of Hours and Earnings Note: Local wages are median Local Authority gross hourly earnings. Plotting the school mean difference from expected progression at the school level.

Appendix Figure A.2: Variation in the presence of secondary Teacher Training

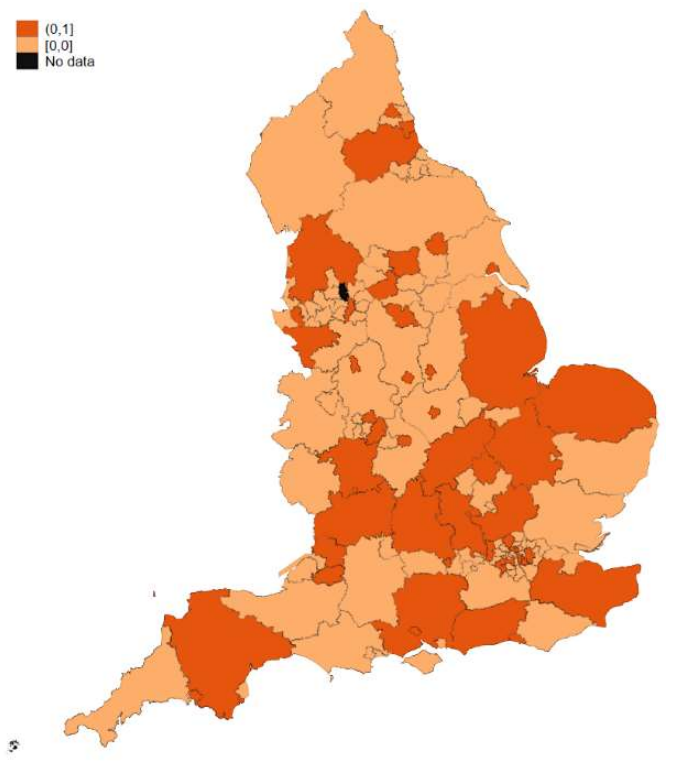

Source: Ofsted management information for inspections of Initial Teacher Training provision.

Note: " 1 " indicates there is a Higher Education Institution that delivers Initial Teacher Training for the secondary phase in the Local Authority. 